\title{
Financial Intermediation and Credit Policy in Business Cycle Analysis*
}

\author{
Mark Gertler and Nobuhiro Kiyotaki \\ N.Y.U. and Princeton
}

October 2009

This version: September 2010

\begin{abstract}
We develop a canonical framework to think about credit market frictions and aggregate economic activity in the context of the current crisis. We use the framework to address two issues in particular: first, how disruptions in financial intermediation can induce a crisis that affects real activity; and second, how various credit market interventions by the central bank and the Treasury of the type we have seen recently, might work to mitigate the crisis. We make use of earlier literature to develop our framework and characterize how very recent literature is incorporating insights from the crisis.
\end{abstract}

*Prepared for the Handbook of Monetary Economics. Thanks to Michael Woodford, David Andolfatto, Larry Christiano, Harris Dellas, Ian Dew-Becker, Giovanni Di Bartolomeo, Chris Erceg, Simon Gilchrist, Arvind Krishnamurthy, Ramon Marimon and Shinichi Nishiyama for helpful comments. Thanks also to Albert Queralto Olive for excellent research assistance. 


\section{Introduction}

To motivate interest in a paper on financial factors in business fluctuations it use to be necessary to appeal either to the Great Depression or to the experiences of many emerging market economies. This is no longer necessary. Over the past few years the United States and much of the industrialized world have experienced the worst financial crisis of the post-war. The global recession that has followed also appears to have been the most severe of this era. At the time of this writing there is evidence that the financial sector has stabilized and the real economy has stopped contracting and output growth has resumed. The path to full recovery, however, remains highly uncertain.

The timing of recent events, though, poses a challenge for writing a Handbook chapter on credit market frictions and aggregate economic activity. It is true that over the last several decades there has been a robust literature in this area. Bernanke, Gertler and Gilchrist (BGG, 1999) surveyed much of the earlier work a decade ago in the Handbook of Macroeconomics. Since the time of that survey, the literature has continued to grow. While much of this work is relevant to the current situation, this literature obviously did not anticipate all the key empirical phenomena that have played out during the current crisis. A new literature that builds on the earlier work is rapidly cropping up to address these issues. Most of these papers, though, are in preliminary working paper form.

Our plan in this chapter is to look both forward and backward. We look forward in the sense that we offer a canonical framework to think about credit market frictions and aggregate economic activity in the context of the current crisis. The framework is not meant as comprehensive description of recent events but rather as a first pass at characterizing some of the key aspects and at laying out issues for future research. We look backward by making use of earlier literature to develop the particular framework we offer. In doing so, we address how this literature may be relevant to the new issues that have arisen. We also, as best we can, characterize how very recent literature is incorporating insights from the crisis.

From our vantage, there are two broad aspects of the crisis that have not been fully captured in work on financial factors in business cycles. First, by all accounts, the current crisis has featured a significant disruption of financial 
intermediation. ${ }^{1}$ Much of the earlier macroeconomics literature with financial frictions emphasized credit market constraints on non-financial borrowers and treated intermediaries largely as a veil (see, e.g. BGG). Second, to combat the crisis, both the monetary and fiscal authorities in many countries including the US. have employed various unconventional policy measures that involve some form of direct lending in credit markets.

From the standpoint of the Federal Reserve, these "credit" policies represent a significant break from tradition. In the post war era, the Federal Reserve scrupulously avoided any exposure to private sector credit risk. However, in the current crisis the central bank has acted to offset the disruption of intermediation by making imperfectly secured loans to financial institutions and by lending directly to high grade non-financial borrowers. In addition, the fiscal authority acting in conjunction with the central bank injected equity into the major banks with the objective of improving credit flows. Though the issue is not without considerable controversy, many observers argue that these interventions helped stabilized financial markets and, as consequence, helped limit the decline of real activity. Since these policies are relatively new, much of the existing literature is silent about them.

With this background in mind, we begin in the next section by developing a baseline model that incorporates financial intermediation into an otherwise frictionless business cycle framework. Our goal is twofold: first to illustrate how disruptions in financial intermediation can induce a crisis that affects real activity; and second, to illustrate how various credit market interventions by the central bank and the Treasury of the type we have seen recently, might work to mitigate the crisis.

As in Bernanke and Gertler (1989), Kiyotaki and Moore (1997a) and others, we endogenize financial market frictions by introducing an agency problem between borrowers and lenders. ${ }^{2}$ The agency problem works to introduce a wedge between the cost of external finance and the opportunity

\footnotetext{
${ }^{1}$ For a description of the disruption of financial intermediation during the current recession, see Brunnermeier (2009), Gorton (2010) and Bernanke (2009). For a more general description of financial crisis over the last several hundred years, see Reinhart and Rogoff (2009).

${ }^{2} \mathrm{~A}$ partial of other macro models with financial frictions in this vein includes, Williamson (1987), Kehoe and Livene (1993), Holmstrom and Tirole (1998), Carlstrom and Fuerst (1997), Caballero and Kristhnamurthy (2001), Kristhnamurthy (2003), Christiano, Motto and Rostagno (2005), Lorenzoni (2008), Fostel and Geanakoplos (2009), and Brunnermeir and Sannikov (2009).
} 
cost of internal finance, which adds to the overall cost of credit that a borrower faces. The size of the external finance premium, further, depends on the condition of borrower balance sheets. Roughly speaking, as a borrower's percentage stake in the outcome of an investment project increases, his or her incentive to deviate from the interests of lenders' declines. The external finance premium then declines as a result.

In general equilibrium, a "financial accelerator" emerges. As balance sheets strengthen with improved economics conditions, the external finance problem declines, which works to enhance borrower spending, thus enhancing the boom. Along the way, there is mutual feedback between the financial and real sectors. In this framework, a crisis is a situation where balance sheets of borrowers deteriorate sharply, possibly associated with a sharp deterioration in asset prices, causing the external finance premium to jump. The impact of the financial distress on the cost of credit then depresses real activity. ${ }^{3}$

Bernanke and Gertler (1989), Kiyotaki and Moore (1997a) and others focus on credit constraints faced by non-financial borrowers. ${ }^{4}$ As we noted earlier, however, the evidence suggests that disruption of financial intermediation is a key feature of both recent and historical crises. Thus we focus our attention here on financial intermediation.

We begin by supposing that financial intermediaries have skills in evaluating and monitoring borrowers, which makes it efficient for credit to flow from lenders to non-financial borrowers through the intermediaries. In particular, we assume that households deposit funds in financial intermediaries that in turn lend funds to non-financial firms. We then introduce an agency problem that potentially constrains the ability of intermediaries to obtain funds from depositors. When the constraint is binding (or there is some chance it may bind), the intermediary's balance sheet limits its ability to obtain deposits. In this instance, the constraint effectively introduces a wedge between the loan and deposit rates. During a crisis, this spread widens substantially, which in turn sharply raises the cost of credit that non-financial borrowers face.

As recent events suggest, however, in a crisis, financial institutions face

\footnotetext{
${ }^{3}$ Most of the models focus on the impact of borrower constraints on producer durable spending. See Monacelli (2009) and Iacoviello (2005) for extensions to consumer durables and housing. Jermann and Quadrini (2009), amongst others, focus on borrowing constraints on employment.

${ }^{4}$ An exception is Holmstrom and Tirole (1997). More recent work includes see He and Kristhnamurthy (2009), and Angeloni and Faia (2009).
} 
difficulty not only in obtaining depositor funds in retail financial markets but also in obtaining funds from one another in wholesale ("inter-bank") markets. Indeed, the first signals of a crisis are often strains in the interbank market. We capture this phenomenon by subjecting financial institutions to idiosyncratic "liquidity" shocks, which have the effect of creating surplus and deficits of funds across financial institutions. If the interbank market works perfectly, then funds flow smoothly from institutions with surplus funds to those in need. In this case, loan rates are thus equalized across different financial institutions. Aggregate behavior in this instance resembles the case of homogeneous intermediaries.

However, to the extent that the agency problem that limits an intermediary's ability to obtain funds from depositors also limits its ability to obtain funds from other financial institutions and to the extent that nonfinancial firms can obtain funds only from a limited set of financial intermediaries, disruptions of inter-bank markets are possible that can affect real activity. In this instance, intermediaries with deficit funds offer higher loan rates to nonfinancial firms than intermediaries with surplus funds. In a crisis this gap widens. Financial markets effectively become segmented and sclerotic. As we show, the inefficient allocation of funds across intermediaries can further depress aggregate activity.

In section 3 we incorporate credit policies within the formal framework. In practice the central bank employed three broad types of policies. The first, which was introduced early in the crisis, was to permit discount window lending to banks secured by private credit. The second, introduced in the wake of the Lehman default was to lend directly in relatively high grade credit markets, including markets in commercial paper, agency debt and mortgagebacked securities. The third (and most controversial) involved direct assistance to large financial institutions, including the equity injections and debt guarantees under the Troubled Assets Relief Program (TARP) as well as the emergency loans to JP Morgan Chase (who took over Bear Stearns) and AIG.

We stress that within our framework, the net benefits from these various credit market interventions are increasing in the severity of the crisis. This helps account for why it makes sense to employ them only in crisis situations.

In section 4 , we use the model to simulate numerically a crisis that has some key features of the current crisis. Absent credit market frictions, the disturbance initiating the crisis induces only a mild recession. With credit frictions (especially those in interbank market), however, an endogenous disruption of financial intermediation works to magnify the downturn. We then 
explore how various credit policies can help mitigate the situation.

Our baseline model is quite parsimonious and meant mainly to exposit the key issues. In section 5, we discuss a number of questions and possible extensions. In some cases, we discuss a relevant literature, stressing the implications of this literature for going forward.

\section{A Canonical Model of Financial Intermedi- ation and Business Fluctuations}

Overall, the specific business cycle model is a hybrid of Gertler and Karadi's (2009) framework that allows for financial intermediation and Kiyotaki and Moore's (2008) framework that allows for liquidity risk. We keep the core macro model simple in order to see clearly the role of intermediation and liquidity. On the other hand, we also allow for some features prevalent in conventional quantitative macro models (such as Christiano, Eichenbaum and Evans (2005), Smets and Wouters (2007)) in order to get rough sense of the importance of the factors we introduce. ${ }^{5}$

For simplicity we restrict attention to a purely real model and only credit policies, as opposed to conventional monetary models. Extending the model to allow for nominal rigidities is straightforward (see., e.g., Gertler and Karadi, 2009), and permits studying conventional monetary policy along with unconventional policies. However, because much of the insight into how credit market frictions may affect real activity and how various credit policies may work can be obtained from studying a purely real model, we abstract from nominal frictions. ${ }^{6}$

\footnotetext{
${ }^{5}$ Some recent monetary DSGE models that incorporate financial factors include Christiano, Motto, and Rostagno (2003,2010) and Gilchrist, Yankov and Zakresjek (2009).

${ }^{6}$ There, however, several insights that monetary models add, however. First, if the zero lower bound on the nominal interest is binding, the financial market disruptions will have a larger effect than otherwise. This is because the central bank is not free to further reduce the nominal rate to offset the crisis. Second, to the extent there are nominal price and/or wage rigidities that induce countercyclical markups, the effect of the credit market disruption and aggregate activity is amplified. See, e.g., Gertler and Karadi (2009) and Del Negro, Ferrero, Eggertsson and Kiyotaki (2010) for an illustration of both of these points.
} 


\subsection{Physical Setup}

Before describing our economy with financial frictions, we present the physical environment.

There are a continuum of firms of mass unity located on a continuum of islands. Each firm produces output using an identical constant returns to scale Cobb-Douglas production function with capital and labor as inputs. Capital is not mobile, but labor is perfectly mobile across firms and islands. Because labor is perfectly mobile, we can express aggregate output $Y_{t}$ as a function of aggregate capital $K_{t}$ and aggregate labor hours $L_{t}$ as:

$$
Y_{t}=A_{t} K_{t}^{\alpha} L_{t}^{1-\alpha}, \quad 0<\alpha<1
$$

where $A_{t}$ is aggregate productivity which follows a Markov process.

Each period investment opportunities arrive randomly to a fraction $\pi^{i}$ of islands. On a fraction $\pi^{n}=1-\pi^{i}$ of islands, there are no investment opportunities. Only firms on islands with investment opportunities can acquire new capital. The arrival of investment opportunities is i.i.d. across time and across islands. The structure of this idiosyncratic risk provides a simple way to introduce liquidity needs by firms, following Kiyotaki and Moore (2008). Let $I_{t}$ denote aggregate investment, $\delta$ the rate of physical deprecation and $\psi_{t+1}$ a shock to the quality of capital. Then the law of motion for capital is given by :

$$
\begin{aligned}
K_{t+1} & =\psi_{t+1}\left[I_{t}+\pi^{i}(1-\delta) K_{t}\right]+\psi_{t+1} \pi^{n}(1-\delta) K_{t} \\
& =\psi_{t+1}\left[I_{t}+(1-\delta) K_{t}\right] .
\end{aligned}
$$

The first term of the right reflects capital accumulated by firms on investing islands and the second is capital that remains on non-investing islands, after depreciation. Summing across islands yields a conventional aggregate relation for the evolution of capital, except for the presence of the disturbance $\psi_{t+1}$, which we refer to as a capital quality shock. Following the finance literature

(e.g., Merton (1973)), we introduce the capital quality shock as a simple way to introduce an exogenous source of variation in the value of capital. As will become clear later, the market price of capital will be endogenous within our framework. In this regard, the capital quality shock will serve as an exogenous trigger of asset price dynamics. The random variable $\psi_{t+1}$ is best thought of as capturing some form of economic obsolescence, as opposed to 
physical depreciation. ${ }^{7}$ We assume the capital quality shock $\psi_{t+1}$ also follows a Markov process. ${ }^{8}$

Firms on investing islands acquire capital from capital goods producers who operate in a national market. There are convex adjustment costs in the gross rate of change in investment for capital goods producers. Aggregate output is divided between household consumption $C_{t}$, investment expenditures, and government consumption $G_{t}$,

$$
Y_{t}=C_{t}+\left[1+f\left(\frac{I_{t}}{I_{t-1}}\right)\right] I_{t}+G_{t}
$$

where $f\left(\frac{I_{t}}{I_{t-1}}\right) I_{t}$ reflects physical adjustment costs, with $f(1)=f^{\prime}(1)=0$ and $f^{\prime \prime}\left(I_{t} / I_{t-1}\right)>0$. Thus the aggregate production function of capital goods producers is decreasing returns to scale in the short-run and is constant returns to scale in the long-run.

Next we turn to preferences:

$$
E_{t} \sum_{i=0}^{\infty} \beta^{i}\left[\ln \left(C_{t+i}-\gamma C_{t+i-1}\right)-\frac{\chi}{1+\varepsilon} L_{t+i}^{1+\varepsilon}\right]
$$

where $E_{t}$ is the expectation operator conditional on date t information and $\gamma \in(0,1)$. We abstract from many frictions in the conventional DSGE framework (e.g. nominal price and wage rigidities, variable capital utilization, etc.). However, we allow both habit formation of consumption and adjustment costs of investment because, as the DSGE literature has found, these features are helpful for reasonable quantitative performance and because they can be kept in the model at minimal cost of additional complexity.

If there were no financial frictions, the competitive equilibrium would correspond to a solution of the planner's problem that involves choosing aggregate quantities $\left(Y_{t}, L_{t}, C_{t}, I_{t}, K_{t+1}\right)$ as a function of the aggregate state

\footnotetext{
${ }^{7}$ One way to motivate this disturbance is to assume that final output is a C.E.S. composite of a continuum of intermediate goods that are in turn produced by employing capital and labor in a Cobb-Douglas production technology. Suppose that, once capital is installed, capital is good-specific and that each period a random fraction of goods become obsolete and are replaced by new goods. The capital used to produced the obsolete goods is now worthless and the capital for the new goods is not fully on line. The aggregate capital stock will then evolve according to equation. (2).

${ }^{8}$ Other recent papers that make use of this kind of disturbance include, Gertler and Karadi (2009), Brunnermeier and Sannikov (2009) and Gourio (2009).
} 
$\left(C_{t-1}, I_{t-1}, K_{t}, A_{t}, \psi_{t}\right)$ in order to maximize the expected discounted utility of the representative household subject to the resource constraints. This frictionless economy (a standard real business cycle model) will serve as a benchmark to which we may compare the implications of the financial frictions.

In what follows we will introduce banks that intermediate funds between households and non-financial firms in a retail financial market. In addition, we will allow for a wholesale inter-bank market, where banks with surplus funds on non-investment islands lend to banks in need of funds on investing islands. We will also introduce financial frictions that may impede credit flows in both the retail and wholesale financial markets and then study the consequences for real activity.

\subsection{Households}

In our economy with credit frictions, households lend to non-financial firms via financial intermediaries. Following Gertler and Karadi (2009), we formulate the household sector in way that permits maintaining the tractability of the representative agent approach.

In particular, there is a representative household with a continuum of members of measure unity. Within the household there are $1-f$ "workers" and $f$ "bankers". Workers supply labor and return their wages to the household. Each banker manages a financial intermediary (which we will call a "bank") and transfers nonnegative dividends back to household subject to its flow of fund constraint. Within the family there is perfect consumption insurance.

Households do not hold capital directly. Rather, they deposit funds in banks. (It may be best to think of them as depositing funds in banks other than the ones they own). In our model, bank deposits are riskless one period securities. Households may also hold riskless one period government debt which is a perfect substitute for bank deposits.

Let $W_{t}$ denote the wage rate, $T_{t}$ lump sum taxes, $R_{t}$ the gross return on riskless debt from $t-1$ to $t, D_{h t}$ the quantity of riskless debt held, and $\Pi_{t}$ net distributions from ownership of both banks and non-financial firms. Then the household chooses consumption, labor supply and riskless debt $\left(C_{t}, L_{t}, D_{h t+1}\right)$ to maximize expected discounted utility (4) subject to the flow of funds constraint, 


$$
C_{t}=W_{t} L_{t}+\Pi_{t}-T_{t}+R_{t} D_{h t}-D_{h t+1} .
$$

Let $u_{C t}$ denote the marginal utility of consumption and $\Lambda_{t, t+1}$ the household's stochastic discount factor. Then the household's first order conditions for labor supply and consumption/saving are given by

$$
\begin{aligned}
& E_{t} u_{C t} W_{t}=\chi L_{t}^{\varepsilon}, \\
& E_{t} \Lambda_{t, t+1} R_{t+1}=1,
\end{aligned}
$$

with

$$
\begin{gathered}
u_{C t} \equiv\left(C_{t}-\gamma C_{t-1}\right)^{-1}-\beta \gamma\left(C_{t+1}-\gamma C_{t}\right)^{-1} \text { and } \\
\Lambda_{t, t+1} \equiv \beta \frac{u_{C t+1}}{u_{C t}} .
\end{gathered}
$$

Because banks may be financially constrained, bankers will retain earnings to accumulate assets. Absent some motive for paying dividends, they may find it optimal to accumulate to the point where the financial constraint they face is no longer binding. In order to limit bankers' ability to save to overcome financial constraints, we allow for turnover between bankers and workers. In particular, we assume that with i.i.d. probability $1-\sigma$, a banker exits next period, (which gives an average survival time $=\frac{1}{1-\sigma}$ ). Upon exiting, a banker transfers retained earnings to the household and becomes a worker. Note that the expected survival time may be quite long (in our baseline calibration it is ten years.) It is critical, however, that the expected horizon is finite, in order to motivate payouts while the financial constraints are still binding.

Each period, $(1-\sigma) f$ workers randomly become bankers, keeping the number in each occupation constant. Finally, because in equilibrium bankers will not be able to operate without any financial resources, each new banker receives a "start up" transfer from the family as a small constant fraction of the total assets of entrepreneurs. Accordingly, $\Pi_{t}$ is net funds transferred to the household:i.e., funds transferred from exiting bankers minus the funds transferred to new bankers (aside from small profits of capital producers).

An alternative to our approach of having a consolidated family of workers and bankers would be to have the two groups as distinct sets of agents, without any consumption insurance between the two groups. It is unlikely, however, that the key results of our paper would change qualitatively. By 
sticking with complete consumption insurance, we are able to have lending and borrowing in equilibrium and still maintain tractability of the representative household approach.

\subsection{Banks}

To finance lending in each period, banks raise funds in a national financial market. Within the national financial market, there is a retail market, where banks obtain deposits from households; and a wholesale market, where banks borrows and lend amongst one and another.

At the beginning of the period each bank raises deposits $d_{t}$ from households in the retail financial market at the deposit rate $R_{t+1}$. After the retail financial market closes, investment opportunities for nonfinancial firms arrive randomly to different islands. Banks can only make loans to nonfinancial firms located on the same island. As we stated earlier, for a fraction $\pi^{i}$ of locations, new investment opportunities are available to finance as well as existing projects. Conversely, for a fraction $\pi^{n}=1-\pi^{i}$, no new investments are available to finance, only existing ones. On the interbank market, banks on islands with new lending opportunities will borrow funds from those on islands with no new project arrivals. ${ }^{9}$

Financial frictions affect real activity in our framework via the impact on funds available to banks. For simplicity, however, there is no friction in transferring funds between a bank and non-financial firms in the same island. In particular, we suppose that the bank is efficient at evaluating and monitoring non-financial firms of the same island, and also at enforcing contractual obligations with these borrowers. We assume the costs to a bank of performing these activities are negligible. Accordingly, given its supply of available funds, a bank can lend frictionlessly to non-financial firms of the same island against their future profits. In this regard, firms are able to offer banks perfectly state-contingent debt. It is simplest to think of the bank's claim on nonfinancial firms as equity.

\footnotetext{
${ }^{9}$ Our model is thus one where liquidity problems emerge in part due to limited market participation, in the spirit of Allen and Gale $(1994,2007)$ and others. This is because within our framework (i) only banks of the same island can make loans to nonfinancial firms and (ii) banks on investing islands cannot raise additional funds in the retail financial market after they learn their customers have investment opportunities.
} 
After learning about its lending opportunities, a bank decides the volume of loans $s_{t}^{h}$ to make to non-financial firms and the volume of interbank borrowing $b_{t}^{h}$ where the superscript $h=i, n$ denotes the island type ( $i$ for investing and $n$ for non-investing) on which the bank is located during the period. Let $Q_{t}^{h}$ be price of a loan (or "asset") - i.e. the market price of the bank's claim on the future returns from one unit of present capital of nonfinancial firm at the end of period. We index the asset price by $h$ because, owing to temporal market segmentation, $Q_{t}^{h}$ may depend on the volume of opportunities that the bank faces.

For an individual bank, the flow-of-funds constraint implies the value of loans funded within a given period, $Q_{t}^{h} s_{t}^{h}$, must equal the sum of the bank net worth $n_{t}^{h}$, its borrowings on the interbank market $b_{t}^{h}$ and deposits $d_{t}$ :

$$
Q_{t}^{h} s_{t}^{h}=n_{t}^{h}+b_{t}^{h}+d_{t} .
$$

Note that $d_{t}$ does not depend upon the volume of the lending opportunities, which is not realized at the time of obtaining deposits.

Let $R_{b t}$ be the interbank interest rate from periods $t-1$ to period $t$. Then net worth at $t$ is the gross payoff from assets funded at $t-1$, net borrowing costs, as follows:

$$
n_{t}^{h}=\left[Z_{t}+(1-\delta) Q_{t}^{h}\right] \psi_{t} s_{t-1}-R_{b t} b_{t-1}-R_{t} d_{t-1},
$$

where $Z_{t}$ is the dividend payment at $t$ on the loans the bank funds at $t-1$. (Recall that $\psi_{t}$ is an exogenous aggregate shock to the quality of capital). Observe that the gross payoff from assets depends on the location specific asset price $Q_{t}^{h}$, which is the reason $n_{t}^{h}$ depends on the realization of the location specific shock at $t$.

Given that the bank pays dividends only when it exits (which occurs with a constant probability), the objective of the bank at the end of period $t$ is the expected present value of future dividends, as follows

$$
V_{t}=E_{t} \sum_{i=1}^{\infty}(1-\sigma) \sigma^{i-1} \Lambda_{t, t+i} n_{t+i}^{h},
$$

where $\Lambda_{t, t+i}$ is the stochastic discount factor, which is equal to the marginal rate of substitution between consumption of date $t+i$ and date $t$ of the representative household.

In order to maintain tractability, we make assumptions to ensure that we do not have to keep track of the distribution of net worth across islands. 
In particular, we allow for arbitrage at the beginning of each period (before investment opportunities arrive) to ensure that ex ante expected rates of return to intermediation are equal across islands. In particular, we suppose that a fraction of banks on islands where expected returns are low can move to islands where they are high at the beginning of each period. Before they move, they sell their existing loans to nonfinancial firms to the other banks that remain on the island in exchange for inter-bank loans that the remaining banks have been holding in their portfolios. These transactions keep each existing loan to nonfinancial firms on the island it was initiated. At the same time, they permit arbitrage to equalize returns across markets ex ante.

As will become clear later, ex ante expected returns being equalized across islands requires that the ratio of total intermediary net worth to total capital on each island be the same at the beginning of each period ${ }^{10}$. Thus, given this arbitrage activity and given that the liquidity shock is i.i.d., we do not have to keep track of the beginning of period distribution of net worth across islands.

To motivate an endogenous constraint on the bank's ability to obtain funds in either the retail or wholesale financial markets, we introduce the following simple agency problem: We assume that after an bank obtains funds, the banker managing the bank may transfer a fraction $\theta$ of "divertable" assets to his or her family. Divertable assets consists of total gross assets $Q_{t}^{h} s_{t}^{h}$ net a fraction $\omega$ of interbank borrowing $b_{t}^{h}$. If a bank diverts assets for its personal gain, it defaults on its debt and is shut down. The creditors may re-claim the remaining fraction $1-\theta$ of funds. Because its creditors recognize the bank's incentive to divert funds, they will restrict the amount they lend. In this way a borrowing constraint may arise.

We allow for the possibility that bank may be constrained not only in obtaining funds from depositors but also in obtaining funds from other banks. Though we permit the tightness of the constraint faced in each market to differ. In particular, the parameter $\omega$ indexes (inversely) the relative degree of friction in the interbank market:

With $\omega=1$, banks cannot divert assets financed by borrowing from other banks: Lending banks are able to perfectly recover the assets that underlie the loans they make. In this case, the interbank market operates frictionlessly,

\footnotetext{
${ }^{10}$ In turn, this requires a movement of net worth from low return to high return islands that is equal in total to the quantity of interbank loans issued in the previous period. The asset exchange between moving and staying banks described in the text accomplishes this arbitrage.
} 
and banks are not constrained in borrowing from one another. They may only be constrained in obtaining funds from depositors.

In contrast, with $\omega=0$, lending banks are no more efficient than depositors in recovering assets from borrowing banks. In this case, the friction that constrains a banks ability to obtaining funds on the interbank market is the same as for the retail financial market. In general, we can allow parameter $\omega$ to differ for borrowing versus lending banks. However, maintaining symmetry simplifies the analysis without affecting the main results.

We assume that the banker's decision over whether to divert funds must be made at the end of the period after the realization of the idiosyncratic uncertainty that determines its type, but before the realization of aggregate uncertainty in the following period. Here the idea is that if the banker is going to divert funds, it takes time to position assets and this must be done between the periods (e.g., during the night). Let $V_{t}\left(s_{t}^{h}, b_{t}^{h}, d_{t}\right)$ be the maximized value of $V_{t}$, given an asset and liability configuration $\left(s_{t}^{h}, b_{t}^{h}, d_{t}\right)$ at the end of period t. Then in order to ensure the bank does not divert funds, the following incentive constraint must hold for each bank type:

$$
V_{t}\left(s_{t}^{h}, b_{t}^{h}, d_{t}\right) \geq \theta\left(Q_{t}^{h} s_{t}^{h}-\omega b_{t}^{h}\right) .
$$

In general the value of the bank at the end of period $t-1$ satisfies the Bellman equation

$$
\begin{aligned}
& V_{t-1}\left(s_{t-1}, b_{t-1}, d_{t-1}\right) \\
= & E_{t-1} \Lambda_{t-1, t} \sum_{h=i, n} \pi^{h}\left\{(1-\sigma) n_{t}^{h}+\sigma \underset{d_{t}}{\operatorname{Max}}\left[\underset{s_{t}^{h}, b_{t}^{h}}{\operatorname{Max}} V_{t}\left(s_{t}^{h}, b_{t}^{h}, d_{t}\right)\right]\right\} .
\end{aligned}
$$

Note that the loans and interbank borrowing are chosen after a shock to the loan opportunity is realized while deposits are chosen before.

To solve the decision problem, we first guess that the value function is linear:

$$
V_{t}\left(s_{t}^{h}, b_{t}^{h}, d_{t}\right)=\nu_{s t} s_{t}^{h}-\nu_{b t} b_{t}^{h}-\nu_{t} d_{t}
$$

where $\nu_{s t}, \nu_{b t}$ and $\nu_{t}$ are time varying parameters, and verify this guess later. Note that $\nu_{s t}$ is the marginal value of assets at the end of period $t ; \nu_{b t}$ is the marginal cost of interbank debt; and $\nu_{t}$ is the marginal cost of deposits. ${ }^{11}$

\footnotetext{
${ }^{11}$ The parameters in the conjectured value function are independent of the individual bank's type because the value function is measured after the bank finishes its transaction for the current this period and because the shock to the loan opportunity is i.i.d. across periods.
} 
Let $\lambda_{t}^{h}$ be the Lagrangian multiplier for the incentive constraint (11) faced by bank of type $h$ and $\bar{\lambda}_{t} \equiv \sum_{h=i, n} \pi^{h} \lambda_{t}^{h}$ be the average of this multiplier across states. Then given the conjectured form of the value function, we may express the first order conditions for $d_{t}, s_{t}^{h}$, and $\lambda_{t}^{h}$, as:

$$
\begin{gathered}
\left(\nu_{b t}-\nu_{t}\right)\left(1+\bar{\lambda}_{t}\right)=\theta \omega \bar{\lambda}_{t} \\
\left(\frac{\nu_{s t}}{Q_{t}^{h}}-\nu_{b t}\right)\left(1+\lambda_{t}^{h}\right)=\lambda_{t}^{h} \theta(1-\omega), \\
{\left[\theta-\left(\frac{\nu_{s t}}{Q_{t}^{h}}-\nu_{t}\right)\right] Q_{t}^{h} s_{t}^{h}-\left[\theta \omega-\left(\nu_{b t}-\nu_{t}\right)\right] b_{t}^{h} \leq \nu_{t} n_{t}^{h} .}
\end{gathered}
$$

According to equation (14), the marginal cost of interbank borrowing exceeds the marginal cost of deposit if and only if the incentive constraint is expected to bind for some state $\left(\bar{\lambda}_{t}>0\right)$ and the inter-bank market operates more efficiently than the retail deposit market (i.e., $\omega>0$, meaning that assets financed by interbank borrowing are harder to divert than those financed by deposits). Equation (15) states that the marginal value of assets in terms of goods $\frac{\nu_{s t}}{Q_{t}^{h}}$ exceeds the marginal cost of interbank borrowing by banks on type $h$ island to the extent that the incentive constraint is binding $\left(\lambda_{t}^{h}>0\right)$ and there is a friction in interbank market $(\omega<1)$. Finally, equation (16) is the incentive constraint. It requires that the values of the bank's net worth (or equity capital), $\nu_{t} n_{t}^{h}$, must be at least as large as weighted measure of assets $Q_{t}^{h} s_{t}^{h}$ net of interbank borrowing $b_{t}^{h}$ that a bank holds. In this way, the agency problem introduces an endogenous balance sheet constraint on banks.

The model for the general case with $0 \leq \omega \leq 1$ is somewhat cumbersome to solve. There are, however, two interesting special cases that provide insight into the models workings. In case 1, there is a perfect interbank market, which arises when $\omega=1$. In case 2 , the frictions in the interbank market are of the same magnitude as in the retail financial market, which arises when $\omega=0$. We next proceed to characterize each of the cases. The Appendix then provides a solution for the general case of an interbank friction with $\omega<1$. 


\subsubsection{Case 1: Frictionless wholesale financial market $(\omega=1)$}

If banks cannot divert assets financed by inter-bank borrowing $(\omega=1)$, interbank lending is frictionless. As equation (15) suggests, perfect arbitrage in the interbank market equalizes the shadow values of assets in each market, implying $\frac{\nu_{s t}}{Q_{t}^{b}}=\frac{\nu_{s t}}{Q_{t}^{t}}$, which in turn implies $Q_{t}^{b}=Q_{t}^{l}=Q_{t}$. The perfect interbank market, further, implies that the marginal value of assets in terms of goods $\frac{\nu_{s t}}{Q_{t}}$ must equal the marginal cost of borrowing on the interbank market $\nu_{b t}$,

$$
\frac{\nu_{s t}}{Q_{t}}=\nu_{b t} .
$$

Because asset prices are equal across island types, we can drop the $h$ superscript in this case. Accordingly, let $\mu_{t}$ denote the excess value of a unit

of assets relative to deposits, i.e., the marginal value of holding assets $\frac{\nu_{s t}}{Q_{t}}$ net the marginal cost of deposits $\nu_{t}$. Then, given that banks are constrained in the retail deposit market, equations (14) and (15) imply that the

$$
\mu_{t} \equiv \frac{\nu_{s t}}{Q_{t}}-\nu_{t}>0 \text {. }
$$

It follows that the incentive constraint (16) in this case may expressed as

$$
Q_{t} s_{t}-b_{t}=\phi_{t} n_{t}
$$

with

$$
\phi_{t}=\frac{\nu_{t}}{\theta-\mu_{t}} .
$$

Note that since interbank borrowing is frictionless, the constraint applies to assets intermediated minus interbank borrowing. How tightly the constraint binds depends positively on the fraction of net assets the bank can divert and negatively on the excess value of bank assets, given by $\mu_{t}$. The higher the excess value is, the greater is the franchise value of the bank and the less likely it is to divert funds.

Let $\Omega_{t+1}$ be the marginal value of net worth at date t+1 and let $R_{k t+1}$ is the gross rate of return on bank assets. Then after combining the conjectured value function with the Bellman equation, we can verify the value function is linear in $\left(s_{t}^{h}, b_{t}^{h}, d_{t}\right)$ if $\mu_{t}$ and $\nu_{t}$ satisfy:

$$
\nu_{t}=E_{t} \Lambda_{t, t+1} \Omega_{t+1} R_{t+1}
$$




$$
\mu_{t}=E_{t} \Lambda_{t, t+1} \Omega_{t+1}\left(R_{k t+1}-R_{t+1}\right)
$$

with

$$
\begin{gathered}
\Omega_{t+1}=1-\sigma+\sigma\left(\nu_{t+1}+\phi_{t+1} \mu_{t+1}\right), \text { and } \\
R_{k t+1}=\psi_{t+1} \frac{Z_{t+1}+(1-\delta) Q_{t+1}}{Q_{t}} .
\end{gathered}
$$

Let us define the "augmented stochastic discount factor" as the stochastic discount factor $\Lambda_{t, t+1}$ weighted by the (stochastic) marginal value of net worth $\Omega_{t+1}$. (The marginal value of net worth is a weighted average of marginal values for exiting and for continuing banks. If a continuing bank has an additional net worth, it can save the cost of deposits and can increase assets by the leverage ratio $\phi_{t+1}$, where assets have an excess value equal to $\mu_{t+1}$ per unit). According to (21), the cost of deposits per unit to the bank $\nu_{t}$ is the expected product of the augmented stochastic discount factor and the deposit rate $R_{t+1}$. Similarly from (22), the excess value of assets per unit, $\mu_{t}$, is the expected product of the augmented stochastic discount factor and the excess return $R_{k t+1}-R_{t+1}$.

Since the leverage ratio net of interbank borrowing, $\phi_{t}$, is independent of both bank-specific factors and island-specific factors, we can sum across individual banks to obtain the relation for the demand for total bank assets $Q_{t} S_{t}$ as a function of total net worth $N_{t}$ as:

$$
Q_{t} S_{t}=\phi_{t} N_{t}
$$

where $\phi_{t}$ is given by equation (20). Overall, a setting with a perfect interbank is isomorphic to one where banks do not face idiosyncratic liquidity risks. Aggregate bank lending is simply constrained by aggregate bank capital.

If the banks' balance sheet constraints are binding in the retail financial market, there will be excess returns on assets over deposits. However, a perfect interbank market leads to arbitrage in returns to assets across market as follows:

$$
E_{t} \Lambda_{t, t+1} \Omega_{t+1} R_{k t+1}=E_{t} \Lambda_{t, t+1} \Omega_{t+1} R_{b t+1}>E_{t} \Lambda_{t, t+1} \Omega_{t+1} R_{t+1} .
$$

As will become clear, a crisis in such economy is associated with an increase in the excess return on assets for banks of all types. 


\subsubsection{Case 2: Symmetric frictions in wholesale and retail financial markets $(\omega=0)$}

In this instance the bank's ability to divert funds is independent of whether the funds are obtained in either the retail or wholesale financial markets. This effectively makes the borrowing constraint the bank faces symmetric in the two credit markets. As a consequence, interbank loans and deposits become perfect substitutes as sources of finance. Accordingly, equation (14) implies that the marginal cost of interbank borrowing is equal to the marginal cost of deposits

$$
\nu_{b t}=\nu_{t}
$$

Here, even if banks on investing islands are financially constrained, banks on non-investing islands may or may not be. Roughly speaking, if the constraint on inter-bank borrowing binds tightly, banks in non-investing islands will be more inclined to use their funds to re-finance existing investments rather than lend them to banks on investing islands. This raises the likelihood that banks on non-investing islands will earn zero excess returns on their assets.

Because asset supply per unit of bank net worth is larger on investing islands than on non-investing islands, the asset price is lower, i.e., $Q_{t}^{i}<Q_{t}^{n}$. Intuitively, given that the leverage ratio constraint limits banks' ability to acquire assets, prices will clear at lower values on investing islands where supplies per unit of bank net worth are greater. In the previous case of a perfect interbank market, funds flow from non-investing to investing islands to equalize asset prices. Here, frictions in the inter-bank market limit the degree of arbitrage, keeping $Q_{t}^{i}$ below $Q_{t}^{n}$.

A lower asset price on the investing island, of course, means a higher

expected return. Let $\mu_{t}^{h} \equiv \frac{\nu_{s t}}{Q_{t}^{h}}-\nu_{t}$ be the excess value of assets on a type $\mathrm{h}$ island. Then we have:

$$
\mu_{t}^{i}>\mu_{t}^{n} \geq 0
$$

The positive excess return implies that banks in the investing islands are finance constrained. Thus the leverage ratios for banks on each island type are given by:

$$
\begin{gathered}
\frac{Q_{t}^{i} s_{t}^{i}}{n_{t}^{i}}=\phi_{t}^{i}=\frac{\nu_{t}}{\theta-\mu_{t}^{i}} \\
\frac{Q_{t}^{n} s_{t}^{n}}{n_{t}^{n}} \leq \phi_{t}^{n}=\frac{\nu_{t}}{\theta-\mu_{t}^{n}}, \text { and }\left(\frac{Q_{t}^{n} s_{t}^{n}}{n_{t}^{n}}-\phi_{t}^{n}\right) \mu_{t}^{n}=0 .
\end{gathered}
$$


In this case the method of undetermined coefficients yields

$$
\begin{gathered}
\nu_{t}=E_{t} \Lambda_{t, t+1} \sum_{h^{\prime}=i, n} \pi^{h^{\prime}} \Omega_{t+1}^{h^{\prime}} R_{t+1}=\underset{h^{\prime}}{E_{t}} \Lambda_{t, t+1} \Omega_{t+1}^{h^{\prime}} R_{t+1} \\
\mu_{t}^{h}=\underset{h^{\prime}}{E_{t} \Lambda_{t, t+1} \Omega_{t+1}^{h^{\prime}}\left(R_{k t+1}^{h h^{\prime}}-R_{t+1}\right)}
\end{gathered}
$$

with

$$
\begin{gathered}
\Omega_{t+1}^{h^{\prime}}=1-\sigma+\sigma\left(\nu_{t+1}+\phi_{t+1}^{h^{\prime}} \mu_{t+1}^{h^{\prime}}\right), \text { and } \\
R_{k t+1}^{h h^{\prime}}=\psi_{t+1} \frac{Z_{t+1}+(1-\delta) Q_{t+1}^{h^{\prime}}}{Q_{t}^{h}} .
\end{gathered}
$$

With an imperfect interbank market, both the marginal value of net worth $\Omega_{t+1}^{h^{\prime}}$ and the return on assets $R_{k t+1}^{h h^{\prime}}$ depend on which island type a bank enters in the subsequent period. Accordingly, we index each by $h^{\prime}$ and take expectations over $h^{\prime}$ conditional on date $\mathrm{t}$ information denoted as $\underset{h^{\prime}}{E_{t}}$.

Because leverage ratios differ across islands, we aggregate separately across bank-types to obtain the aggregate relations:

$$
\begin{gathered}
Q_{t}^{i} S_{t}^{i}=\phi_{t}^{i} N_{t}^{i} \\
Q_{t}^{n} S_{t}^{n} \leq \phi_{t}^{n} N_{t}^{n}, \text { and }\left(Q_{t}^{n} S_{t}^{n}-\phi_{t}^{n} N_{t}^{n}\right) \mu_{t}^{n}=0,
\end{gathered}
$$

where $\phi_{t}^{i}$ and $\phi_{t}^{n}$ are given by equations (27) and (28). As we will see, in the general equilibrium, investment will depend on the price of capital on "investing" islands, $Q_{t}^{i}$. Accordingly, it is the aggregate balance sheet constraint on asset demand for banks on investing islands, given by equation (31) that becomes critical for interactions between financial conditions and production.

Next, from $(25,26,29,30)$, we learn that the returns obey

$$
\begin{aligned}
\underset{h^{\prime}}{E_{t}} \Lambda_{t, t+1} \Omega_{t+1}^{h^{\prime}} R_{k t+1}^{i h^{\prime}} & >\underset{h^{\prime}}{E_{t}} \Lambda_{t, t+1} \Omega_{t+1}^{h^{\prime}} R_{k t+1}^{n h^{\prime}} \\
& \geq \underset{h^{\prime}}{E_{t} \Lambda_{t, t+1} \Omega_{t+1}^{h^{\prime}} R_{b t+1}}=\underset{h^{\prime}}{E_{t} \Lambda_{t, t+1} \Omega_{t+1}^{h^{\prime}} R_{t+1} .}
\end{aligned}
$$

with $\geq$ holds with strict inequality iff $\mu_{t}^{n}>0$ and holds with equality iff $\mu_{t}^{n}=0$. With an imperfect inter-bank market, a crisis is associated with both a rise in the excess return for banks on investing islands and increase in the dispersion of returns between island types. 
As we show in Appendix, for the case where the interbank market is imperfect but operates with less friction than the retail deposit market (i.e., $0<\omega<1$ ), the interbank rate will lie between the return on loans and the deposit rates. Intuitively, because a dollar interbank credit will tighten the incentive constraint by less than a dollar of deposits (since lending banks are able to recover a greater fraction of creditor assets than are depositors), the interbank rate exceeds the deposit rate. However, because lending banks are not able to perfectly recover assets $\omega<1$, there is still imperfect arbitrage which keeps the expected discounted interbank rate below the expected discounted rate of return to loans.

\subsection{Evolution of Bank Net Worth}

Let total net worth for type h banks, $N_{t}^{h}$, equal the sum of the net worth of existing bankers $N_{o t}^{h}$ ( $o$ for old) and of entering bankers $N_{y t}^{h}$ ( $y$ for young):

$$
N_{t}^{h}=N_{o t}^{h}+N_{y t}^{h}
$$

Net worth of existing bankers equals earnings on assets net debt payments made in the previous period, multiplied by the fraction that survive until the current period, $\sigma$ :

$$
N_{o t}^{h}=\sigma \pi^{h}\left\{\left[Z_{t}+(1-\delta) Q_{t}^{h}\right] \psi_{t} S_{t-1}-R_{t} D_{t-1}\right\} .
$$

Because the arrival of investment opportunity is independent across time, the interbank loans are net out in the aggregate here. We assume that the family transfers to each new banker is the fraction $\xi /(1-\sigma)$ of the total value assets of exiting bankers, implying:

$$
N_{y t}^{h}=\xi \pi^{h}\left[Z_{t}+(1-\delta) Q_{t}^{h}\right] \psi_{t} S_{t-1}
$$

Finally, by the balance-sheet of the entire banking sector, deposits equal the difference between total assets and bank net worth as follows,

$$
D_{t}=\sum_{h=i, n}\left(Q_{t}^{h} S_{t}^{h}-N_{t}^{h}\right)
$$

Observe that the evolution of net worth depends fluctuations in the return to assets.. Further, the higher the leverage of the bank is, the larger will be the percentage impact of return fluctuations on net worth. Note also that a 
deterioration of capital quality (a decline in $\psi_{t}$ ) directly reduces net worth. As we will show, there will also be a second round effect, as the decline in net worth induces a fire sale of assets, depressing asset prices and thus further depressing bank net worth.

\subsection{Nonfinancial Firms}

There are two types of non-financial firms: goods producers and capital producers.

\subsubsection{Goods Producer}

Competitive goods producers on different islands operate a constant returns to scale technology with capital and labor inputs, given by equation (1). Since labor is perfectly mobile across islands, firms choose labor to satisfy

$$
W_{t}=(1-\alpha) \frac{Y_{t}}{L_{t}}
$$

It follows that we may express gross profits per unit of capital $Z_{t}$ as follows:

$$
Z_{t}=\frac{Y_{t}-W_{t} L_{t}}{K_{t}}=\alpha A_{t}\left(\frac{L_{t}}{K_{t}}\right)^{1-\alpha} .
$$

As we noted earlier, conditional on obtaining funds from a bank, a goods producer does not face any further financial frictions and can commit to pay all the future gross profits to the creditor bank. A goods producer with an opportunity to invest obtains funds from an intermediary by issuing new state-contingent securities (equity) at the price $Q_{t}^{i}$. The producer then uses the funds to buy new capital goods from capital goods producers. Each unit of equity is a state-contingent claim to the future returns from one unit of investment:

$$
\psi_{t+1} Z_{t+1},(1-\delta) \psi_{t+1} \psi_{t+2} Z_{t+2},(1-\delta)^{2} \psi_{t+1} \psi_{t+2} \psi_{t+3} Z_{t+3}, \ldots
$$

Through perfect competition, the price of new capital goods is equal to $Q_{t}^{i}$, and goods producers earn zero profits state-by-state.

Note that given constant returns and perfect labor mobility, we do not have keep track of the distribution of capital across islands. As in the standard competitive model with constant returns, the size distribution of firms is indeterminate. 


\subsection{Capital Goods Producers}

Capital producers operate in a national market. They make new capital using input of final output and subject to adjustment costs, as described in section 2.1. They sell new capital to firms on investing islands at the price $Q_{t}^{i}$. Given that households own capital producers, the objective of a capital producer is to choose $I_{t}$ to solve:

$$
\max E_{t} \sum_{\tau=t}^{\infty} \Lambda_{t, \tau}\left\{Q_{\tau}^{i} I_{\tau}-\left[1+f\left(\frac{I_{\tau}}{I_{\tau-1}}\right)\right] I_{\tau}\right\}
$$

From profit maximization, the price of capital goods is equal to the marginal cost of investment goods production as follows,

$$
Q_{t}^{i}=1+f\left(\frac{I_{t}}{I_{t-1}}\right)+\frac{I_{t}}{I_{t-1}} f^{\prime}\left(\frac{I_{t}}{I_{t-1}}\right)-E_{t} \Lambda_{t, t+1}\left(\frac{I_{t+1}}{I_{t}}\right)^{2} f^{\prime}\left(\frac{I_{t+1}}{I_{t}}\right)
$$

Profits (which arise only outside of steady state), are redistributed lump sum to households.

\subsection{Equilibrium}

To close the model (in the case without government policy), we require market clearing in both the market for securities and the labor market. Total securities issued on investing and non-investing islands correspond to aggregate capital acquired by each type, as follows:

$$
\begin{aligned}
S_{t}^{i} & =I_{t}+(1-\delta) \pi^{i} K_{t} \\
S_{t}^{n} & =(1-\delta) \pi^{n} K_{t} .
\end{aligned}
$$

Note that demand for securities by banks is given by equation (23) in the case of a frictionless interbank market and by equations (31) and (32) in the case of an imperfect interbank market. Observe first that the market price of capital on each island type will in general depend on the financial condition of the associated banks. Second, with an imperfect interbank market, the asset price will be generally lower (or, equivalently,state-contingent loans rates offered by banks will be generally greater) on investing islands than elsewhere. $^{12}$

\footnotetext{
${ }^{12}$ This verifies the earlier conjecture in Section 2.3.2. For the more general case of imperfect interbank market, see Appendix 1.
} 
Finally, the condition that labor demand equals labor supply requires that

$$
(1-\alpha) \frac{Y_{t}}{L_{t}} \cdot E_{t} u_{C t}=\chi L_{t}^{\varepsilon}
$$

Because of Walras' Law, once the market for goods, labor, securities, and interbank loans is cleared, the market for riskless debt will be cleared automatically:

$$
D_{h t}=D_{t}+D_{g t},
$$

where $D_{g t}$ is supply of government debt. This completes the description of the model.

Absent credit market frictions, the model reduces to a real business cycle framework modified with habit formation and flow investment adjustment costs. With the credit market frictions, however, balance sheet constraints on banks ability to obtain funds in retail and wholesale market may limit real investment spending, affecting aggregate real activity. As we will show, a crisis is possible where weakening of bank balance sheets significantly disrupts credit flows, depressing real activity.

As we have discussed, one example of a factor that could weaken bank balance sheets is a deterioration of the underlying quality of capital. A negative quality shock directly reduces the value of bank net worth, forcing banks to reduce asset holdings. A second round effect on bank net worth arises as the fire sale of assets reduces the market price of capital. Further, the overall impact on bank equity of the decline in asset values is proportionate to the amount of bank leverage. With highly leveraged banks, a substantial percentage drop in bank equity may arise, leading to a significant disruption of credit flows. We illustrate this point clearly in section 4 .

\section{Credit Policies}

During the crisis the various central banks, including the US. Federal Reserve, made use of their powers as a lender of last resort to facilitate credit flows. To justify such actions, the Federal Reserve appealed to Section 13.3 of the Federal Reserve Act, which permits it in "unusual end exigent circumstances" to make loans to the private sector, so long as the loans are judged to be of sufficiently high grade. The statute makes clear that in normal times the Federal Reserve is not permitted to take on private credit risk. In a crisis, 
however, the Federal Reserve has freedom to fulfill its responsibility as lender of last resort, provided that it does not absorb undue risk.

In practice, the Federal Reserve employed three general types of credit policies. First, early on it expanded discount window operations by permitting discount window loans to be collateralized by high grade private securities and also by extending the availability of the window to non-bank financial institutions. Second, the Federal Reserve lent directly in high grade credit markets, funding assets that included commercial paper, agency debt and mortgage backed securities. Third, the Treasury, acting in concert with the Federal Reserve, injected equity in the banking system along with supplying bank debt guarantees (together with the Federal Deposit Insurance Corporation).

There is some evidence that these types of policies were effective in stabilizing the financial system. The expanded liquidity helped smooth the flow of funds between financial institutions, effectively by dampening the turmoilinduced increases in the spread between the interbank lending rate (LIBOR) and the Treasury Bill rate. The enhanced financial distress following the Lehmann failure, however, proved to be too much for the liquidity facilities alone to handle. At this point, the Federal Reserve set up facilities to lend directly to the commercial paper market and a number of weeks later phased in programs to purchase agency debt and mortgage backed securities. Credit spreads in each these markets fell.

The equity injections also came soon after Lehmann. Though not without controversy, the equity injections appeared to reduce stress in banking markets. Upon the initial injection of equity in mid-October 2008, credit default swap rates of the major banks fell dramatically. At the time of this writing, the receiving banks have paid back a considerable portion of the funds. Further, though risks remain, the government appears to have made money on many of these programs.

In the sub-sections below, we take a first pass at analyzing how these policies work, using our baseline model. ${ }^{13}$ As we showed in the previous section, within the context of our model, the financial market frictions open the possibility of periods of distress where excess returns on assets are abnormally high. Because they are balance sheet constrained, private financial intermediaries cannot immediately arbitrage these returns. One can view

\footnotetext{
${ }^{13}$ For related attempts to model credit policy, see Curdia and Woodford (2009a, 2009b), Reis (2009), and Sargent and Wallace (1983).
} 
the point of the Federal Reserve's various credit programs as facilitating this arbitrage in times of crisis. In this regard, each of the various policies works somewhat differently, as we discuss below.

Before proceeding, we emphasize that, consistent with the Federal Reserve Act, we have in mind that these interventions be used only during crises and not during normal times. Indeed, within the logic of the model, the net benefits from credit policy are increasing in the distortion of credit markets that the crisis induces, as measured by the excess return on capital.

\subsection{Lending Facilities (Direct Lending)}

We characterize direct lending broadly as the facilities the Federal Reserve set up for direct acquisition of high quality private securities.

Lending facilities work as follows: We suppose that the central bank has both an advantage and a disadvantage relative to private lenders. The advantage is that unlike private intermediaries, the central bank is not balance sheet constrained (at least in the same way). Private citizens do not have to worry about the central bank defaulting. The liabilities it issues are government debt and it can credibly commit to honoring this debt (aside from inflation). Thus, in periods of distress where private intermediaries are unable to obtain additional funds, the central bank can obtain funds and then channel them to markets with abnormal excess returns. ${ }^{14}$

In the current crisis, the Federal Reserve funded the initial expansion of its lending programs by issuing government debt (that it borrowed from the Treasury) and then later made use of interest bearing reserves. The latter are effectively government debt. It is true that the interest rate on reserves fell to zero as the Federal Funds rate reached its lower bound, giving these reserves the appearance of money. However, once the Federal Reserve moves the Funds rate above zero it will also raise the interest rate on reserves. In this regard, the Federal Reserve's unconventional policies should be thought of as expanded central intermediation as opposed to expanding the money supply. In the case of lending facilities, a key advantage of the central bank is that it is

\footnotetext{
${ }^{14}$ Others have also emphasized how that special nature of government liabilities can give rise to a productive role for government financial intermediations. See, example, Sargent and Wallace (1983), Kiyotaki and Moore (2008), Gertler and Karadi (2009), and Shleifer and Vishny (2010). As originally noted by Wallace (1980), unless there is something special about government liabilities, the Miller-Modigliani theorem applies to government finance.
} 
not constrained in its ability to funds the same way as private intermediaries may be in time of financial distress. Another equally important advantage is that the Federal Reserve can lend in many markets. By contrast, private banks face a limited market participation constraint, i.e., they can only lend to nonfinancial firms of the same island.

At the same time, we suppose that the central bank is less efficient at intermediating funds. It faces an efficiency cost $\tau$ per unit, which may be thought of as a cost of evaluating and monitoring borrowers that is above and beyond what a private intermediary (who has specific knowledge of a particular market) would pay. ${ }^{15}$

To obtain funds, the central bank issues government debt to the private that is a perfect substitute for bank deposits, and pays the riskless real rate $R_{t+1}$. It lends the funds in market $h$ at the private loan rate $R_{k t+1}^{h h^{\prime}}$ which depends upon the state of the next period $h^{\prime}$. Observe that the central banks is not offering the funds at a subsidized rate. However, by expanding the supply of funds available in the market, it will reduce equilibrium lending rates.

Let $S_{t}^{h}$ be total securities of type $h$ intermediated, $S_{p t}^{h}$ total securities of type $h$ intermediated by private banks, and $S_{g t}^{h}$ total type $h$ securities intermediated by the central bank. Then total intermediation of type $h$ assets is given by:

$$
Q_{t}^{h} S_{t}^{h}=Q_{t}^{h}\left(S_{p t}^{h}+S_{g t}^{h}\right)
$$

We suppose the central bank chooses to intermediate the fraction $\varphi_{t}^{h}$ of total credit in market $h$ :

$$
S_{g t}^{h}=\varphi_{t}^{h} S_{t}^{h}
$$

where $\varphi_{t}^{h}$ may be thought of as an instrument of central bank credit policy.

Assuming that banks investing regions are constrained under a symmetric frictions in wholesale and retail financial markets $(\omega=0)$, lending facilities expand the total amount of assets intermediated in the market. Combining equations (31), (43) and (44), yields

$$
Q_{t}^{i} S_{t}^{i}=\frac{1}{1-\varphi_{t}^{i}} \phi_{t}^{i} N_{t}^{i}
$$

\footnotetext{
${ }^{15}$ Other potential costs include the potential for politicization of credit flows. We abstract from this consideration, though we think it provides another important reason for why credit policies are more appropriate in crises than normal times.
} 
The effect on asset demand for non-investing regions depends on whether or not banks in these regions are balance sheet constrained (i.e., on whether the excess return $\mu_{t}^{n}>0$ is positive). If they are, then lending facilities affect asset demands similarly to the way they do in investing regions, only the superscript $i$ is replaced by $n$ in (45). One other hand, if banks in non-investing regions are not constrained (i.e., $\mu_{t}^{n}=0$ ), then central bank credit merely displaces private credit, leaving total asset demand in the sector unaffected. Let $S_{t}^{n *}$ be total asset demand consistent with a zero excess return on assets on non-investing islands in equilibrium. Then

$$
Q_{t}^{n} S_{t}^{n *}=Q_{t}^{n} S_{p t}^{n}+\varphi_{t}^{n} Q_{t}^{n} S_{t}^{n *}, \text { iff } \mu_{t}^{n}=0 .
$$

Here an increase in central credit provision crowds out private intermediation one for one. Only when private intermediaries are financially constrained does central bank intermediation expand the overall supply of credit.

\subsection{Liquidity Facilities (Discount Window Lending)}

With liquidity facilities, the central bank uses the discount window to lend funds to banks that in turn lend them out to nonfinancial borrowers. Typically, liquidity facilitates are used to offset disruption of inter-bank markets. Such was the case in the current crisis.

Another distinguishing feature of liquidity facilities is that central bank lending is typically done at a penalty rate. This prescription dates back to Bagehot (1873). The idea is that during a liquidity crises, it is the breakdown of markets for short term funds that is responsible for many borrowers having limited credit access, as opposed to lack of credit worthiness of individual borrowers. Because excess returns for these borrowers are abnormally high during the crisis, they are more than willing to borrow at penalty rates. Offering the funds at a penalty rate, further, discourages inefficient use of central bank credit by the private sector.

In this section we use our model to illustrate how discount window lending may facilitate the flow of inter-bank lending during a crisis. To do so, we restrict attention to the case $(\omega=0)$, where borrowers in the inter-bank market face symmetric constraints on obtaining funds in both the wholesale and retail markets. In this instance, banks with surplus funds face the same risk as depositors that borrowing banks may divert a fraction of gross assets for their own purposes. 
We suppose the central bank offers discount window credit at the noncontingent interest rate $R_{m t+1}$ to banks who borrow on the inter-bank market. It funds this activity by issuing government debt that is a perfect substitute for household deposits. For discount window lending to expand the supply of funds in the inter-bank market, however, the central bank must have an advantage over private lenders in supplying funds to borrowing banks. Otherwise discount window lending will simply supplant private inter-bank lending.

Here we suppose that the central bank is better able to enforce repayment than private lenders. In particular for any unit of discount window credit supplied, a borrowing bank can divert only the fraction $\theta\left(1-\omega_{g}\right)$ of assets, with $0<\omega_{g} \leq 1$. Recall that for credit supplied by a private lender, the borrowing bank can divert the fraction $\theta>\theta\left(1-\omega_{g}\right)$. Here the idea is that the government may have additional means at its disposal (IRS records, access to credit records, legal punishments, etc.) to retrieve assets. We suppose, however, that after a certain level of discount window lending, the central bank's ability to retrieve assets more efficiently than the private sector disappears. Think of this as reflecting some capacity constraint on the central bank's ability to efficiently process discounted window loans secured by private credit. ${ }^{16}$

Let $m_{t}^{h}$ be discount window borrowing for a bank of type $h$. The flow of funds constraint is now,

$$
Q_{t}^{h} s_{t}^{h}=n_{t}^{h}+b_{t}^{h}+m_{t}^{h}+d_{t} .
$$

with $m_{t}^{h} \geq 0$. Let $V_{t}\left(s_{t}^{h}, b_{t}^{h}, m_{t}^{h}, d_{t}\right)$ be the value of a bank who holds assets and liabilities $\left(s_{t}^{h}, b_{t}^{h}, m_{t}^{h}, d_{t}\right)$ at the end of period $t$. For the bank to continue operating this value must not fall below the gain from diverting assets, taking into account the central bank's advantage in retrieving assets. Accordingly, in this case the incentive constraint is given by:

$$
V_{t}\left(s_{t}^{h}, b_{t}^{h}, m_{t}^{h}, d_{t}\right) \geq \theta\left(Q_{t}^{h} s_{t}^{h}-\omega_{g} m_{t}^{h}\right) .
$$

\footnotetext{
${ }^{16}$ Alternatively, if we had asset heterogeneity this constraint might reflect a limitation on the kind of bank assets that might be suitable collateral for discount window lending. For example, information-intensive commercial and industrial loans are not good collateral for discount window loans since they require expertise for monitoring and evaluation. On the other hand, agency debt or high grade securitized mortgage might be suitable, but banks might only have a limited fraction in their portfolios.
} 
We defer the details of the bank's decision problem for this case to the Appendix. Accordingly, let $\mu_{m t}$ be the excess cost to a bank of discount window credit relative to deposits

$$
\mu_{m t}=\underset{h^{\prime}}{E_{t}} \Lambda_{t, t+1} \Omega_{t+1}^{h^{\prime}}\left(R_{m t+1}-R_{t+1}\right) .
$$

Next note that, because we are restricting attention to the case of symmetric frictions in private interbank and retail financial markets $(\omega=0)$, the interbank rate equals the deposit rate: $R_{b t+1}=R_{t+1}$. Then from the first order conditions we learn that in order for both private interbank borrowing and discount window to be actively used, we need:

$$
\mu_{m t}=\omega_{g} \mu_{t}^{i}
$$

where $\mu_{t}^{i}$ is the excess value of assets on investing islands, given by equation (30).

According to equation (50), to make borrowers indifferent between discount window and private credit at the margin, the central bank should set $R_{m t+1}$ to make the excess cost of discount window credit equal to the fraction $\omega^{g}$ of the excess value of assets. Intuitively, because a unit of discount window credit permits a borrowing bank to expand assets by a greater amount than a unit private interbank credit, it is willing to pay a higher cost for this form of credit. In this way, the model generates an endogenously determined penalty rate for discount window lending.

Let $M_{t}$ be the total supply of discount window credit offered to the market. Then one can show that the market demand for assets by investing banks is given by

$$
Q_{t}^{i} S_{p t}^{i}=\phi_{t}^{i} N_{t}^{i}+\omega_{g} M_{t} .
$$

Thus, so long as $\omega_{g}>0$, discount window lending can expand the total level of assets intermediated by banks on investing regions.

Because the excess value of bank assets on non-investing islands is less than that on investing islands, i.e., $\mu_{t}^{n}<\mu_{t}^{i}$., banks on non-investing islands will not borrow from the discount window. Given that the discount rate is set to satisfy equation (50) discount window lending will be too expensive for banks who do not have new investment to finance.

The question then arises as to why the central bank does not simply expand discount lending to drive excess values of assets to zero. As we noted earlier, it reasonable to suppose that there are capacity constraints on 
the central bank's ability to adequately monitor bank's asset management activities, (even though we do not formally incorporate it into our model here). With a capacity constraint on discount window lending (secured by private credit) the central bank may need to use other tools such as direct lending or equity injections during crisis periods of high excess returns. While liquidity facilities may be useful for improving the flow of funds in inter-bank markets, in a major crisis other kinds of interventions may be necessary to stabilize financial markets.

\subsection{Equity Injections.}

With equity injections, the fiscal authority coordinates with the monetary authority to acquire ownership positions in banks. As with direct central bank lending we suppose that there are efficiency costs associated with government acquisition of equity. Let this cost be $\tau_{e}$ per unit of equity acquired. During a financial crisis, however, the net benefits from equity injections may be positive and significant.

The effect of equity injections depends on three factors: (i) the payout rule for government equity; (ii) the price at which the government acquires the equity relative to the market price; and (iii) the advantage the government might have relative to private creditors in addressing the agency problem with banks.

The government injects equity into banks who stay active (instead of exiting) at the beginning of period before banks learn whether their customers have opportunities to invest or not. This is different from the direct lending and discount window lending activities of the central bank that are conducted after the arrival of investment opportunities. By this difference in timing, we try to capture a feature that the equity injections are slower than the direct lending and discount window lending. For simplicity we restrict attention to the case with a perfect interbank market in which banks cannot divert assets that are financed by interbank borrowing. (See the Appendix for a general case). Then the asset price is equal across regions with different investment opportunity.

We suppose that a unit of government equity has the same payout stream as a unit of private equity. The government may hold the equity stake until the bank exits and then receive the liquidation value of its assets, equal to 
$Z_{\tau}+(1-\delta) Q_{\tau}$ per unit of capital times the number of units of capital its shares are worth. Alternatively it may sell off its holding at this value before the bank exits, assuming the crisis has passed.

Accordingly, one can effectively divide the total number of securities held by the bank at time $t$ between those privately owned, $s_{p t}$, and those publicly owned, $s_{\text {get }}$ :

$$
s_{t}=s_{p t}+s_{g e t}
$$

Let $n_{g t}$ be the market value of government equity. The bank's balance sheet identity then implies:

$$
Q_{t} s_{t}=n_{t}+b_{t}+d_{t}+n_{g t}
$$

where each security the government holds is valued at the market price $Q_{t}$, implying:

$$
n_{g t}=Q_{t} s_{g e t}
$$

To acquire equity, the government may pay a price $Q_{g t}$ that is above $Q_{t}$. One rationale for the government paying a premium is that the market price is below its normal value due to financial distress. For example, the government could pick $Q_{g t}$ so that the excess return on government equity, $\mu_{g t}$, equals zero, as follows:

$$
\mu_{g t}=E_{t} \Lambda_{t, t+1} \Omega_{t+1}\left(R_{g k t+1}-R_{t+1}\right)
$$

where $R_{g k t+1}$ is the gross return on a unit of government equity injected at time $t$ is:

$$
R_{g k t+1}=\psi_{t+1} \frac{Z_{t+1}+(1-\delta) Q_{t+1}}{Q_{g t}}
$$

Since the excess return of private equity is positive (see equation (22)), $Q_{g t}>$ $Q_{t}$.

The premium the government pays for equity is effectively a transfer to the bank that shows up in its net worth as follows:

$n_{t}=\left[Z_{t}+(1-\delta) Q_{t}\right] \psi_{t} s_{p t-1}-R_{b t} b_{t-1}-R_{t} d_{t-1}+\left(Q_{g t}-Q_{t}\right)\left[s_{g e t}-(1-\delta) \psi_{t} s_{g e t-1}\right]$

where $\left(Q_{g t}-Q_{t}\right)\left[s_{\text {get }}-(1-\delta) \psi_{t} s_{\text {get }-1}\right]$ is the "gift" to the bank from new government equity purchases. 
We suppose that the bank cannot divert assets financed by government equity. As with discount window lending, the government has an advantage relative to the private creditors in recovering assets. Accordingly, the incentive constraint becomes,

$$
V_{t}\left(s_{t}-s_{g e t}, b_{t}, d_{t}\right) \geq \theta\left(Q_{t}\left(s_{t}-s_{g e t}\right)-b_{t}\right) .
$$

where as before $b_{t}$ is interbank borrowing (with $\omega=1$ ).

Let $N_{g t}$ be total government equity in the banking system and $S_{g t}$ be total holdings of government equity. Then we can aggregate to obtain the following expressions for aggregate asset demand and for the evolution of net worth:

$$
\begin{gathered}
Q_{t} S_{t}=\phi_{t} N_{t}+N_{g t} \\
N_{t}=(\sigma+\xi)\left[Z_{t}+(1-\delta) Q_{t}\right] \psi_{t} S_{p t-1}-\sigma R_{t} D_{t-1}+\left(Q_{g t}-Q_{t}\right)\left[S_{g e t}-(1-\delta) \psi_{t} S_{g e t-1}\right]
\end{gathered}
$$

where $\phi_{t}$ is the leverage ratio privately intermediated assets in the case of a perfect inter-bank market (see equation (20)), and with $N_{g t}=Q_{t} S_{g e t}$. Thus, in this case equity injections expand the value of assets intermediated onefor-one, as equation (58) suggests. In addition, to the extent the government paying pays a premium over the market price (which is depressed due to the financial crisis), the equity injection also expands private bank net worth, as equation (59) indicates. This is in turn expands asset demand by a multiple equal to the leverage ratio $\phi_{t}$.

One additional important effect of government equity injections is they reduce the impact of unanticipated changes in asset values on private bank equity. Absent government equity, for example, the bank absorbs entirely the loss from an unanticipated decline in asset values, given that its obligations to outsiders are all in the form of non-contingent debt. With public equity, however, the government shares proportionately in the loss.

A key question now is what might determine the allocation of credit policy intervention between direct lending, discount window lending and equity injections. We argued earlier that in the context of our model, it might be natural to think of capacity constraints on discount window lending secured by private credit. So long as the efficiency costs of direct central bank lending are not large, extensive use of the direct lending makes sense. For high grade instruments like commercial paper, agency debt and mortgage backed securities it is reasonable to suppose the costs of central bank intermediation are not large. This might account for why direct central bank lending in the 
current crisis involved these kinds of assets. On the other hand, it is easy to imagine that other forms of bank lending, such as commercial and industrialized loans, which involve extensive evaluation and monitoring, would be quite costly for the central bank to intermediate. In this case, in a period of crisis, equity injections that enhance the ability of private banks to make these kinds of loans would seem desirable, (if the efficiency cost of government equity injection is not too large.) In our model, capital is homogeneous. Getting at this issue, accordingly, will involve extending our framework to allow for asset heterogeneity.

\subsection{Government Expenditures and Budget Constraint}

Here government consumption $G_{t}$ consists of "normal" government expenditures $\bar{G}$ and intermediation expenditures. Let $S_{g t}^{h}$ be total securities of type $h=i, n$ acquired via direct central bank lending and $S_{g e t}$ securities acquired via equity injections. Then $G_{t}$ is given by

$$
G_{t}=\bar{G}+\tau_{e} S_{g e t}+\tau \sum_{h=i, n} S_{g t}^{h}
$$

Putting together fiscal and monetary authority, government expenditures are financed by lump sum taxes $T_{t}$ and net earnings from credit market interventions as,

$$
\begin{aligned}
& G_{t}+Q_{g t}\left[S_{g e t}-(1-\delta) \psi_{t} S_{g e t-1}\right]+\sum_{h=i, n} Q_{t}^{h}\left[S_{g t}^{h}-(1-\delta) \psi_{t} S_{g t-1}\right] \\
= & T_{t}+Z_{t} \psi_{t}\left(S_{g t-1}+S_{g e t-1}\right)+R_{m t} M_{t-1}-M_{t}+D_{g t}-R_{t} D_{g t-1}
\end{aligned}
$$

where $M_{t}$ is total discount window lending and $D_{g t}$ is government bond. As we discussed earlier, the price the government pays for equity, $Q_{g t}$, could exceed the market price.

Note that the during the crisis the government will earn extra returns on its portfolio, since excess private returns in the market are positive, but private intermediaries are constrained from exploiting this. On the other hand, the government may takes losses on its portfolio. Here we assume that lump sum taxes adjust to finance the losses. It would be interesting though to consider distortionary taxes to get a better sense of the costs faced in pursuing these policies. 


\section{Crisis Simulations and Policy Experiments}

In this section we present some numerical experiments designed to illustrate how the model may capture some key features of a financial crisis and also how credit policy might work to mitigate the crisis. The analysis is meant only to be suggestive. In this regard, our aim is to show how vulnerability of the financial system might propagate the effects of a disturbance to asset values and aggregate production that might otherwise have a relatively modest effect on the economy. In addition to identifying the significance of balance sheet effects on intermediaries in the process, we also isolate the importance of an imperfect inter-bank market.

We start with the calibration and then turn to a "crisis" simulation. After examining how the crisis plays out in the absence of any kind of policy response, we analyze how credit policy might work to mitigate the crisis. We focus on direct lending since this policy is the simplest to present. Though, we do not report the results here, the other policies ultimately affect the economy in a similar fashion.

\subsection{Calibration}

There are eleven parameters for which we need to assign values. Seven are standard preference and technology parameters. These include the discount factor $\beta$, the habit parameter $\gamma$, the utility weight on labor $\chi$, the inverse of the Frisch elasticity of labor supply $\varepsilon$, the capital share parameter $\alpha$, the depreciation rate $\delta$ and the elasticity of the price of capital with respect to investment $\eta$. For these parameters we use reasonably conventional values, as reported in Table 1. The one exception involves the labor supply elasticity: To compensate partly for the absence of labor market frictions, we use a Frisch labor elasticity of ten, which is well above the range found in the business cycle literature, which typically lies between unity and three. We emphasize, though that this compensation is only partial: Had we instead incorporated the various key of quantitative DSGE models, including variable capital utilization and nominal price and wage rigidities, employment volatility in our framework would be much greater, even with a conventional labor supply elasticity.

The four additional parameters are specific to our model. The first is the probability of an investment opportunity, $\pi^{i}$. The last three are the financial sector parameters: $\sigma$ the quarterly survival probability of bankers; $\xi$ the 
transfer parameter for new bankers, and $\theta$ the fraction of gross assets the banker can divert. We set $\pi^{i}$ equal to 0.25 , implying that new investment opportunities on a island arise once a year on average. We set $\sigma=0.975$, implying that bankers survive for ten years on average.

Finally, we choose $\xi$ and $\theta$ to hit the following two targets: an average credit spread of one hundred basis points per year and an economy-wide leverage ratio of four. The choice of a leverage ratio of four reflects a crude first pass attempt to average across sectors with vastly different financial structures. For example, before the beginning of the crisis, most housing finance was intermediated by financial institutions with leverage ratios between twenty (commercial banks) and thirty (investment banks.) The total housing stock, however, was only about a third of the overall capital stock. Leverage ratios are clearly smaller in other sectors of the economy. We base the steady state target for the spread on the pre-2007 spreads as a rough average of the following spreads: mortgage rates versus government bond rates, BAA corporate bond rates versus government bonds, and commercial paper rates versus $\mathrm{T}$-Bill rates.

We consider both the case of a perfect inter-bank market $(\omega=1)$ and of an imperfect inter-bank market $(\omega=0)$. As we noted earlier, with an perfect inter-bank market, the model economy behaves as if banks were homogenous and did not face an idiosyncratic arrival of lending opportunities. Under our calibration, within a local region of the steady state, all banks are symmetrically constrained, i.e., have similar excess returns on assets.

With an imperfect inter-bank market, under our calibration only banks on investing islands are constrained (within a local region of the steady-state). Those on non-investing islands have sufficient funds relative to lending opportunities to bid the price on assets to the point where the excess return over deposit costs is zero. They lend surplus funds to banks in investing region. For reasonable variations of our calibration, banks remain unconstraint in non-investing regions and remain constrained in investing regions.

Finally, we suppose that the capital quality shock obeys a first order autoregressive process. 


\subsection{Crisis Experiment}

\subsubsection{No Policy Response}

We now turn to the crisis experiment. Broadly speaking, what triggered the recent financial crisis was a decline in real estate values that precipitated a wave of losses on mortgage backed securities held by financial intermediaries. Our model is not sufficiently rich to capture precisely this phenomenon, particularly since it does not include housing. The initiating feature of the current crisis that we can capture, however, is the deterioration in value of intermediary portfolios.

In particular, the initiating disturbance we consider is an exogenous decline in capital quality. ${ }^{17}$ What we are trying to capture in a simple way is an exogenous force that triggers a decline in the value of intermediary assets. Within the model economy, the initial exogenous decline is then magnified in two ways. First, because banks are leveraged, the effect of decline in assets values on bank net worth is enhanced by a factor equal to the leverage ratio. Second, the drop in net worth tightens the banks' borrowing constraint inducing effectively a fire sale of assets that further depresses asset values. The crisis then feeds into real activity as the decline in asset values leads to a fall in investment.

The initiating disturbance is a five percent unanticipated decline in capital quality with an autoregressive factor of 0.66 . We fix the size of the shock simply to produce a downturn of roughly similar magnitude to the one observed over the 2008-2009 financial crisis.

We began by analyzing the performance of the model economy without credit policy and we start with the case of a perfect inter-bank market. Figure 1 reports the impulse responses of the key economic variables to a negative shock to capital quality. The dotted line is the model without financial frictions and the solid line is our baseline model with a perfect inter-bank market.

Note first that the negative disturbance produces only a modest downturn in the frictionless model. The loss of capital initially produces a drop

\footnotetext{
${ }^{17}$ What is critical for our crisis experiment is that the initiating disturbance lead to a decline in the market prices of intermediary assets. Another type of disturbances that could initiate a decline in asset values would be an unfavorable "news shock" about the future payoff to capital as in Gilchirst and Leahy (2002), Christiano, Motto and Rostagno (2010) or Gourio (2009). Yet another possibility would be to introduce "noise" shocks, as in L'Ao (2010).
} 
in output and consumption. However, high returns to capital induce an increase in investment and employment. Therefore without financial frictions, the economy smoothly converges to a normal state as in a Cass-Koopmans optimal growth model with a smaller initial capital stock than the steady state.

With financial frictions the output decline at the trough is roughly twice as large as in the frictionless case. It is also significantly more protracted. The five percent decline in the quality of capital leads to a roughly fifty percent decline in bank net worth. The magnified effect is due to bank leverage and to the fall in the market price capital, arising from the fire sale of assets induced by the tightening of bank borrowing constraints. The contraction in asset prices induces a decline in investment that is nearly double the output decline. Of course, it is the enhanced decline in investment that is ultimately responsible for the magnified drop in output in the case with financial frictions. Finally, the employment drop, while nearly several percentage points larger than in the frictionless case, is relatively modest. This simply reflects the absence of various standard labor market frictions that would enhance the response.

That financial factors are at work during the crisis is reflected in the behavior of the spread between the expected return to capital and the riskless interest rate. In the frictionless model this spread does not move (to a first order.) In the case with financial frictions, the spread rises on impact as a product of the decline in bank net worth. The increase in the cost of capital is responsible for the magnified drop in investment and output.

Financial factors also contribute to the slow recovery back to trend. To reduce the spread between the expected return to capital and the riskless rate remain, bank net worth must increase. But this process takes time, as the figure shows. So long as the spread is above trend, financial factors are a drag on the real economy. Note that throughout this convergence process, banks are effectively deleveraging since they are building up equity relative to debt. This, in a way, the model captures how the deleveraging process can slow down a recovery.

Next we turn to the case with the imperfect inter-bank market in Figure 2. Observe that frictions in the interbank market magnify the overall decline. The overall decline in investment is roughly a third larger relative to the perfect interbank market case, the output decline twenty percent larger, and the employment decline nearly double. Intuitively, in this case investing banks are limited in there ability to obtain funds on the inter-bank market 
once the crisis hits. In addition, banks on investing islands have higher leverage than those on non-investing islands because the asset price is lower in investing islands. Accordingly, asset prices in investing islands fall by more than they otherwise would, leading to an enhanced drop in overall investment. Symptomatic of the imperfect inter-bank market is the sharp rise in the spread between the return on capital and the riskless rate, which increases well above five percent, as compared to one percent in the case of a perfect interbank market.

\subsubsection{Credit Policy Response}

Here we analyze the impact of direct central bank lending as a means to mitigate the impact of the crisis. Symptomatic of the financial distress in the simulated crisis is a large increase in the spread between the expected return on capital on investing islands and the riskless interest rate. In practice, further, it was the appearance of abnormally large credit spreads in various markets that induced the Federal Reserve to intervene with credit policy. Accordingly we suppose that the Federal Reserve adjusts the fraction of private credit it intermediates to the difference between spread on investing islands, $\left(E_{t} R_{k t+1}^{i h^{\prime}}-R_{t+1}\right)$, and its steady state value $\left(E R_{k}^{i h^{\prime}}-R\right)$, as:

$$
\varphi_{t}=v_{g}\left[\left(E_{t} R_{k t+1}^{i h^{\prime}}-R_{t+1}\right)-\left(E R_{k}^{i h^{\prime}}-R\right)\right]
$$

To be clear, the rule applies only during a crisis, i.e., during "unusual and exigent" circumstances.

We begin with the case a perfect interbank market. In this case the return on assets is equalized across islands. It does not matter to which locale the central bank supplies credit. If it intermediates funds on non-investing islands, banks in these locations will lend any surplus funds to banks on investing islands to the point where the return on assets is equalized across locations.

We set the policy parameter $v_{g}$ equal to 100 . Figure 3 reports the impulses for this case. The policy intervention dampens the overall decline in output by nearly one third. The increase in central bank credit significantly reduces the rise in the spread, which in turn reduces the overall drop in investment. At is peaks, central bank credit increases to slightly over ten percent of the capital stock. 
With an imperfect interbank market the central bank acquires assets on investing islands. What we have in mind here is that the central bank is targeting assets with high excess returns, i.e. assets that may be underfunded due to shortages of intermediary capital in the relevant market. Note that by charging the market rate to borrowers in these regions, the policy screens out borrowers on non-investing islands who earn lower returns.

Figure 4 reports the results for this case. The credit policy similarly works to dampen the output decline by mitigating the increase in the spread. Interestingly, the policy is more effective at containing the crisis in this case. What matters in this case are the leverage constraints on bank borrowing in investing locations, as opposed to leverage constraints economy-wide. By directly facilitating credit flows in investing regions, a given level of central bank intermediation can be more effective in relaxing financial constraints. Note in this case that at the peak, central bank credit intermediation is only about five percent of total assets intermediated, which is less than half of what it was in the economy of frictionless interbank market. However, it is roughly twenty percent of assets intermediated in investing regions. The high percentage of central bank intermediation in this distressed region is what accounts for the effectiveness of the policy. This occurs even though total central bank intermediation is smaller than in the case of the perfectinterbank market.

As we noted earlier, both discount window lending and equity injections work in a similar fashion to mitigate a crisis. It would be interesting to extend our framework to allow for features like asset heterogeneity and so on that would make it clearer how credit market interventions should be allocated between the three approaches.

Finally, though we do not do the exercise here, one can evaluate the net welfare benefits from the credit policy intervention, given different assumptions about the efficiency costs of direct central bank lending, following Gertler and Karadi (2009). As these authors show, however, under reasonable assumptions about these costs, the net benefits to the intervention are large and approximately equal to the gross benefits. They are also increasing in the severity of the crisis. 


\section{$5 \quad$ Issues and Extensions}

We now discuss some key issues in the literature that our baseline model does not consider. We also characterize how one might extend our framework to address these issues.

\section{$5.1 \quad$ Tightening Margins}

Within our baseline model, financial distress is a product of deteriorating intermediary balance sheets: A decline in intermediary net worth forces a decline in the value of assets the intermediary can hold, given the constraint on its leverage ratio induced by the principal-agent problem.

Another complementary way that financial distress can transmit to the real economy is by a tightening of the leverage ratio, as emphasized by Adrian and Shin (2009), Brunnermeier and Pederson (2009), Kiyotaki and Moore (2008), Jermann and Quadrini (2009), Fostel and Geanakoplos (2009), Kurlat (2009) and others.

In the context of our model, any factor that might reduce the fraction of assets that lenders can expect to recover in a default will induce a tightening of margins. Recall that the fraction of assets that depositors can recover is $1-\theta$, while banks who lend in the interbank can recover the fraction $1-\theta(1-\omega)$, with $0<\omega<1$. Suppose now that $\theta$ and $\omega$ might vary. The incentive constraint that determines that maximum leverage ratio becomes

$$
V_{t}\left(s_{t}^{h}, b_{t}^{h}, d_{t}\right) \geq \theta_{t}\left(Q_{t}^{h} s_{t}^{h}-\omega_{t} b_{t}^{h}\right),
$$

where the $t$ subscripts $\theta_{t}$ and $\omega_{t}$ allow for the possibility of time variation.

An increase in $\theta_{t}$ and/or a reduction in $\omega_{t}$ clearly tightens the incentive constraint. One can then show that this leads to to tightening of margins, since lenders will permit less borrowing for any given level of net worth. Kiyotaki and Moore (2008), Del Negro, Eggertsson, Ferrero and Kiyotaki (2010) and Jermann and Quadrini (2009) use essentially this kind of mechanism to motivate a disruption of financial markets. Intuitively, $\theta_{t}$ is related inversely to the efficiency of the deposit market and the product $\theta_{t}\left(1-\omega_{t}\right)$ is related to the efficiency of the interbank market. The less lenders are able to recover from borrowers in either of these market, everything else equal, the less efficient are financial markets. 
In the context of our model, one could imagine forces that lead $\theta_{t}$ and $\omega_{t}$ to move endogenously. For example, a deterioration in overall asset quality might make it more difficult for lenders to recover assets (particularly if the quality decline makes the assets relatively more specific to the borrowers), leading to an increase in $\theta_{t}$. If the recovery problem is concentrated in the inter-bank market, then the deterioration in asset quality might induce a reduction in $\omega_{t}$, causing the interbank market to contract. In either case, an endogenous response of $\theta_{t}$ and $\omega_{t}$ is likely to magnify the crisis.

There is work that attempts to model the tightening of margins explicitly. For example, Eisfeldt (2004) and Kurlat (2009) have frameworks where adverse selection problems are countercyclical. The greater degree of adverse selection in recessions causes a tightening of margins in the secondary financial market in downturns (which is similar to a reduction of $\omega_{t}$ ). A much earlier paper by Williamson (1987) motivates something similar to an increase in $\theta_{t}$ in the primary financial market. In this framework, the agency problem that introduces the financial market friction is based on Townsend's (1979) costly state verification (CSV) model. Within the CSV model, the agency costs are expected default costs, which are increasing in the spread of the idiosyncratic shock to the borrower's return distribution. As Williamson shows, if the idiosyncratic risk is countercyclical, agency costs also become countercyclical, which leads a tightening of margins in downturns. Curdia (2007), Christiano, Motto and Rostagno (2009), and Gilchrist, Yankov and Zakresjek incorporate a similar mechanism in contemporary quantitative macroeconomic frameworks. Finally, Fostel and Geanakoplos (2009)) also appeal to increases in uncertainty to motivate a tightening of margins, but do so in a setup with heterogeneous beliefs and disagreement.

Another way to allow for tightening of margins is to allow for a precautionary effect on asset holdings. Within our framework, given constant returns at the intermediary level, the leverage ratio is always binding: Banks always hold the maximum level of assets that their respective net worth permits. Aiyagari and Gertler (1999) and Mendoza (2009) relax this assumption. As they show, even if the leverage (or margin) constraint is not currently binding, an increased likelihood that it could be binding in the future (due possibly to increased uncertainty) can also induce a tightening of margins., Brunnermeier and Sannikov (2009) and He and Krishnamurthy (2008) also present frameworks where precautionary effects can lead to a tightening of margins. Importantly, within these frameworks, the banks net worth still influences 
asset holdings. ${ }^{18}$ A stronger net worth position, everything else equal, reduces the likelihood the margin constraint will be binding, which encourages the intermediary to expand asset holdings.

\subsection{Regulatory Arbitrage and Securitized Lending}

Because we are interested in capturing the interaction between banking and the macroeconomic conditions our representation of the financial intermediary sector is quite parsimonious. We restrict attention to features of financial intermediation that we think are absolutely essential to characterizing this interaction. At the same time, our framework captures three basic aspects of banking that have been emphasized in the literature. ${ }^{19}$ First, banks act as delegated monitors. Because evaluating and monitoring borrowers requires specialized expertise, the financial intermediaries within our model operate as conduits that channel funds from households to firms. Second, banks engage in maturity transformation. They issue short term liabilities and hold long term assets. Third, they facilitate liquidity provision. Within our framework the interbank market (when it is functioning well) works to ensures that borrowers with idiosyncratic needs for funds receive them.

The banks within our model are best thought of as a consolidated representation of the financial intermediary sector, which includes commercial and investment banks. In this regard our baseline framework does not capture some notable details of the current financial crisis. In particular, a salient future of the current crisis was the unraveling of the investment banks which held securitized assets that in many instances were originated and sold off by commercial banks. However, we can extend our model to capture an aspect of this phenomenon. ${ }^{20}$

In particular, suppose the banker operates a commercial bank that faces binding regulatory capital requirement. In reaction to this regulatory requirement the banker sets up a special purpose vehicle (SPV) that is not subject

\footnotetext{
${ }^{18}$ These models also have constant returns at the intermediary level. However, they do not restrict attention to log linear approximations of the model and instead they allow for higher order effects of uncertainty on decision-making.

${ }^{19}$ See, for example, Diamond, (1984), Diamond and Dybvig (1983), Holmstrom and Tirole (1997) and the survey by Allen, Babua and Carletti (2009) for discussions of basic aspects of banking.

${ }^{20}$ Shleifier and Vishny (2009) also emphasis the role of securitized lending in the crisis.
} 
to the regulatory requirements on capital. The banker places in the SPV assets that the commercial bank originated and securitized. He funds the SPV partly by allocating some of his own net worth to the entity and partly by issuing short term debt that is a perfect substitute for bank deposits.

Think of the overall entity that the banker runs as a universal bank with the commercial bank and the SPV as separate entities. Because it operates off the commercial bank's balance sheet and holds securitized assets, the SPV may be thought of as an investment bank.

The key point is that the universal bank in this case will behave exactly like the financial intermediary in our baseline scenario. In particular, from the standpoint of the universal bank's creditors, what matters is its consolidated balance sheet and not the breakdown of assets and liabilities between the commercial bank and the SPV. Thus, agency problem between the banker and his creditors introduces a maximum permissible leverage ratio for the universal bank as a whole. For simplicity, we abstract from liquidity risks (i.e., $\pi^{i}=1$ ) so that asset prices are equalized across regions. Then it is straightforward to show that the maximum leverage ratio for the universal bank is $\phi_{t}$, as given by (20).

Now suppose that the maximum regulatory leverage on the commercial bank $\phi^{b}$ is lower than the privately determined value $\phi_{t}$. In addition, suppose that the SPV is able to operate with a leverage ratio $\phi_{t}^{s p v}$ that exceeds $\phi_{t}$ :

$$
\phi^{b}<\phi_{t}<\phi_{t}^{s p v}
$$

where the superscript $b$ denotes commercial bank and the superscript spv denote SPV. Then the universal bank can always find a division of assets and net worth of the commercial bank and the SPV which satisfies the capital requirement on the commercial bank while at the same time satisfying the privately determined leverage constraint for the universal bank:

$$
\begin{aligned}
Q_{t} s_{t}^{b} & \leq \phi^{b} n_{t}^{b} \\
Q_{t} s_{t}^{s p v} & \leq \phi_{t}^{s p v} n_{t}^{s p v} \\
Q_{t}\left(s_{t}^{b}+s_{t}^{s p v}\right) & =\phi_{t}\left(n_{t}^{b}+n_{t}^{s p v}\right) .
\end{aligned}
$$

Here, the universal bank uses the SPV and securitization in order to circumvent the regulation on the commercial bank. ${ }^{21}$ The only binding leverage

\footnotetext{
${ }^{21}$ In practice, a key factor in the growth of investment banks holding of securitized assets was the increase in capital requirements on commercial banks, phased in after the banking crises of the 1980s.
} 
constraint is the consolidated leverage constraint (64) which results from the incentive constraint of the universal bank. Then, while the model now contains securitized lending and assets held off commercial bank balance sheets, the macroeconomic equilibrium is the same as in our baseline framework. Thus, at a first pass, the addition of these features does not alter the predictions of the model about the feedback between the financial and real sectors that magnifies the crisis. Our enriched model will predict that during a crisis, investment banking, securitized lending and commercial banking will all be disrupted, as happened in practice.

Here we have made the strong assumption that the commercial bank and the SPV have a single ownership. It would be interesting to relax this assumption. At the same time, during the crisis, the commercial bank and the SPV did not have a completely arms length relationship. In many instances as the crisis unfolded commercial banks repurchased securitized assets they had originally sold to other institutions. It would be useful to try to capture this implicit relationship between commercial banks and SPV.

\subsection{Outside Equity, Externalities and Moral Hazard}

Our baseline presumes that the only type of liability the bank can issue to raise funds is short term non-contingent debt. We now explore the possibility that the bank can issue fully state-contingent debt or, equivalently, outside equity. As we show, outside equity issuance is desirable because it provides a hedge to the bank against fluctuations in its net worth. At the same time we consider how an agency problem might limit a bank's use of outside equity financing. We also show that externalities and the anticipation of government credit market intervention can lead a bank to rely too little on outside equity, which introduces a possible role for regulatory capital requirements.

We now allow bankers to issue outside equity. We suppose that a unit of outside equity entitles the holder to the same dividend payout per share as banker's asset. Let $q_{t}$ be market price of a unit of outside bank equity and $e_{t}$ the quantity issued. We restrict attention to the case of perfect interbank market (i.e., $\omega=1$ ) and refer the reader to Appendix for a more general treatment. Then the bank's balance sheet is given by

$$
Q_{t} s_{t}=n_{t}+b_{t}+d_{t}+q_{t} e_{t}
$$

The flow of funds constraint becomes 


$$
n_{t}=\left[Z_{t}+(1-\delta) Q_{t}\right] \psi_{t} s_{t-1}-\left[Z_{t}+(1-\delta) q_{t}\right] \psi_{t} e_{t-1}-R_{b t} b_{t-1}-R_{t} d_{t-1}
$$

By issuing outside equity the bank is able to have its creditors share part of the risk in the payoff to its loan portfolio. For example, a negative capital quality shock (fall in $\psi_{t}$ ) is not absorbed entirely by the bank but also by the bank's outside equity holders. Put differently, by issuing outside equity, the bank reduces its leverage ratio and, by do so, reduces the volatility of its net worth.

Given the hedging value that outside equity affords, everything else equal, the bank would prefer to replace its non-contingent debt with perfectly statecontingent equity. Accordingly, everything else equal, the bank gains by reducing the volatility of its net worth. This then begs the question of why banks do not fund assets with equity or fully state-contingent debt. A classic argument by Calomiris and Kahn (1991) is that short term debt provides a disciplining device on bank behavior. The need to meet continual noncontingent payments reduces the degree to which a bank can in any way act against the interest of its creditors to favor its owners.

One way to illustrate the Calomiris and Kahn argument in the context of our model is as follows: Suppose that it is easier for the banker to divert assets funded by equity than assets funded by deposit. It may take time for outside equity holders to assess whether a suspension or reduction of dividend payments reflects the true condition of bank assets or some malfeasance on the part of the banker. On the other hand, because deposits requires immediate payment, it is difficult for the banker to quickly divert funds.

To be concrete, suppose that the bank can divert the fraction $\theta\left(1-\omega_{e}\right)$ of assets fund by equity where $\omega_{e}<0$, but only the fraction $\theta$ funded by short term debt. (The banker cannot divert assets fund by interbank loan since $\omega=1$ here). We can now express the incentive constraint as:

$$
V_{t}\left(s_{t}, b_{t}, d_{t}, e_{t}\right) \geq \theta\left(Q_{t} s_{t}-\omega_{e} q_{t} e_{t}-b_{t}\right)
$$

where $V_{t}\left(s_{t}, b_{t}, d_{t}, e_{t}\right)$ is the bank's continuation value conditional on it raising funds by outside equity as well as by debt. The second term on the right reflects the fact that it is easier for the bank to divert assets funded by equity $\left(\right.$ as $\left.\omega_{e}<0\right)$.

Let $R_{e t+1}$ be the return on bank equity: 


$$
R_{e t+1}=\psi_{t+1} \frac{Z_{t+1}+(1-\delta) q_{t+1}}{q_{t}}
$$

Then as the Appendix shows, the first order conditions from the banks portfolio structure problem are given

$$
E_{t} \Lambda_{t, t+1} \Omega_{t+1}\left(R_{t+1}-R_{e t+1}\right)=\left(-\omega_{e}\right) \cdot E_{t} \Lambda_{t, t+1} \Omega_{t+1}\left(R_{k t+1}-R_{t+1}\right)
$$

If the incentive constraint is binding then following the reasoning in section 2 , there are excess returns to bank assets, i.e., the expected discounted return to bank assets $E_{t} \Lambda_{t, t+1} \Omega_{t+1} R_{k t+1}$ exceeds the expected discounted cost of bank deposits, $E_{t} \Lambda_{t, t+1} \Omega_{t+1} R_{t+1}$. This makes the right side of the equation positive. The left side then implies that for banks to be issuing both deposits and outside equity, the discounted cost of the outside equity, $E_{t} \Lambda_{t, t+1} \Omega_{t+1} R_{e t+1}$, must be less than that of that of deposits.. Intuitively, changing the mix of financing from deposits to outside equity tightens the incentive constraint. For the bank to be indifferent between the financing sources the cost of outside equity must be less than the cost of deposits.

The household's portfolio decision introduces the following arbitrage relation between the deposit rate and the return on bank equity.

$$
E_{t} \Lambda_{t, t+1} R_{t+1}=E_{t} \Lambda_{t, t+1} R_{e t+1}
$$

Observe that the household discounts the stock return $R_{e t+1}$ by the stochastic factor $\Lambda_{t, t+1}$ while the banker uses a discount factor that is augmented by the shadow value of net worth $\Omega_{t+1}$, which varies counter-cyclically. The net effect is that the banker's expected discounted cost of issuing equity is less than the household's expected discounted return to holding it. The difference is due to the fact that outside equity provides a hedge for the bank against fluctuations in net worth, something which the bank values directly but the household does not.

To understand the implications for the bank's liability structure, first consider the case where $\omega_{e}=0$, i.e., shifting from deposit finance to outside equity does not enhance the enforcement problem. It follow from equation (68) that for the bank to use both financing options, the cost must be equal to the banker. Otherwise it will exclusively use the lower cost option. Given that the household's arbitrage condition governs the link between the deposit rate and the return on bank equity, it is straight-forward to show that, due 
to its hedging value, outside equity offers the lower cost financing option for the bank. Thus in this instance, the bank would choose to finance exclusively with outside equity (or, equivalently) fully state-contingent debt.

The situation changes, however, if outside equity enhances the incentive problems. If $\omega_{e}$ is sufficiently negative (meaning that outside equity is subject to a significantly greater agency problem than are deposits), the bank may not be able to offer a return on bank equity that is competitive with the return on deposits. In this instance, the bank will resort exclusively to deposit finance.

Thus, one can appeal to an agency problem to motivate why the bank might rely mainly on non-contingent deposit as opposed to outside equity. But here it is important to recognize that there is an externality present in private sector financial structure decisions. In particular, as section 2 makes clear, the volatility of returns on banks and conversely the volatility of the economy depends on the aggregate balance sheet of the intermediary sector as opposed to the balance sheet of any individual intermediary. That is, it is the leverage ratio of the sector as a whole, that makes the financial system vulnerable to disturbances.

Individual banks do not take into account the effects of their own liability structure on the aggregate. At the bank level, this distorts the decision in favor of debt financing and away from the use of outside equity. As a consequence, the aggregate balance sheet features more leverage than a social planner would prefer. This raises the possibility that some form of capital requirements may be optimal. Korinek (2009) and Lorenzoni (2008) have made similar types of arguments.

The introduction of an endogenous choice of equity also raises the issue of moral hazard from the anticipation of policy interventions. The credit policies we described earlier work to stabilize the volatility in banks' shadow value of net worth. Doing so, however, reduces the banks incentive to resort to outside equity financing. This in turn raises the aggregate leverage in the intermediary sector, increasing the likelihood of another crisis that might require government intervention. Tracing out these moral hazard consequences is an important direction for future research. Some recent work that has explored this issue in a different setting from ours includes, Diamond and Rajan (2009), Farhi and Tirole (2009) and Chari and Kehoe (2010). In our view, capturing the quantitative implications of moral hazard is particularly important for policy evaluation. 


\section{Concluding Remarks}

If nothing else, we hope that our Handbook chapter helps dispel the notion that macroeconomists have not paid attention to the financial sector. As we have seen, over the past twenty years there has been a steady stream of research that incorporates financial frictions into macroeconomic analysis. The crisis, of course, has precipitated an uptick in the pace of this research and offered many new issues to study.

One difference between research over the past decade as compared to earlier has been an emphasis on developing frameworks suitable for quantitative analysis. We view this as a welcome development since many of the issues involving the role of financial factors in the business cycle and the implications for both credit and regulatory policies ultimately involve quantitative considerations. Our best guess is at the time of the writing of the next Handbook chapter on this topic, the authors will be reviewing macroeconomic models with financial sectors that perform credibly from an empirical standpoint and that provide sharps insights for public policy. 


\section{References}

[1] Adrian, Tobias, and Hyun Shin, 2009. "Money, Liquidity and Monetary Policy," Federal Reserve Bank of New York and Princeton University, Mimeo.

[2] Aiyagari, Rao and Mark Gertler, 1999. "Overreaction of Asset Prices in General Equilibrium," Rev. of Econ. Dyn. 2:3-35.

[3] Allen, Franklin, Ana Babus and Elena Carletti, "Financial Crises: Theory and Evidence," University of Pennsylvania, Mimeo.

[4] Allen, Franklin, and Douglas Gale, 1994. "Limited Market Participation and Volatility of Asset Prices," Am. Econ. Rev. 84:933-955.

[5] Allen, Franklin, and Douglas Gale, 2007. Understanding Financial Crises. Oxford University Press, Oxford, UK.

[6] Angeloni, Ignazio and Ester Faia, 2009. "A Tale of Two Policies: Prudential Regulation and Monetary Policy with Fragile Banks," European Central Bank, Mimeo.

[7] Bagehot, Walter, 1873, Lombard Street: A Description of the Money Market: A description of money market. H. S. King, London, UK.

[8] Bernanke, Ben, (2009), "The Crisis and the Policy Response," Jan. 13 speech.

[9] Bernanke, Ben and Mark Gertler, 1989, "Agency Costs, Net Worth and Business Fluctuations," Am. Econ. Rev. 79:14-31.

[10] Bernanke, Ben, Mark Gertler, and Simon Gilchrist, 1999, "The Financial Accelerator in a Quantitative Business Cycle Framework," Taylor, J., Woodford, M. (Eds.), Handbook of Macroeconomics, 1:1341-1393, Elsevier, Amsterdam, Netherlands.

[11] Brunnermeier, Markus, 2009, "Deciphering the Liquidity and Credit Crunch 2007-2008," J. Econ. Perspec. 23:77-100.

[12] Brunnermeier, Markus and Lasse Pederson, 2009, "Market Liquidity and Funding Liquidity," Rev. Financ. Stud. 22:2201-2238. 
[13] Brunnermeier, Markus and Yuliy Sannikov, 2009, "A Macroeconomic Model with a Financial Sector," Princeton University, Mimeo.

[14] Caballero, Ricardo, and Arvind Krishnamurthy, 2001, "International and Domestic Collateral Constraints in a Model of Emerging Market Crises," J. Monet. Econ. 48:513-548.

[15] Calomiros, Charles, and Charles Kahn, 1991, "The Role of Demandable Debt in Structuring Banking Arrangements, Am. Econ. Rev. 81:497-513.

[16] Carlstrom, Charles and Timothy Fuerst, 1997, "Agency Costs, Net Worth and Business Fluctuations: A Computable General Equilibrium Analysis", Am. Econ. Rev. 97:893-910.

[17] Chari. V.V., and Patrick Kehoe, 2010, "Bailouts, Time Consistency and Optimal Regulation," University of Minnesota, Mimeo.

[18] Christiano, Lawrence, Martin Eichenbaum and Charles Evans, 2005, "Nominal Rigidities and the Dynamics Effects of a Shock to Monetary Policy,", J. of Poli. Econ. 113:1-45.

[19] Christiano, L., R. Motto and M. Rostagno, 2005, "The Great Depression and the Friedman Schwartz Hypothesis," J. of Money Credit and Bank. 35:1119-1198.

[20] Christiano, L., R. Motto and M. Rostagno, 2009, "Financial Factors in Business Fluctuations," Northwestern University, Mimeo.

[21] Curdia, Vasco, 2007, "Monetary Policy Under Sudden Stops," Federal Reserve Bank of New York, Mimeo.

[22] Curdia, Vasco and Michael Woodford, 2009a,. "Credit Spreads and Monetary Policy," Federal Reserve Bank of New York and Columbia University, Mimoe.

[23] Curdia, Vasco and Michael Woodford, 2009b,. "Conventional and Unconventional Monetary Policy," Federal Reserve Bank of New York and Columbia University, Mimeo.

[24] Del Negro, Marco, Gauti Eggertsson, Andrea Ferrero and Nobuhiro Kiyotaki 2010. "The Great Escape?" Federal Reserve Bank of New York and Princeton University, Mimeo. 
[25] Diamond, Douglas, 1984, "Financial Intermediation and Delegated Monitoring" Review of Econ. Stud. 51:393-414.

[26] Diamond, Douglas, and Philip Dybvig, 1983. "Bank Runs, Deposit Insurance and Liquidity," Journal of Political Economy, 91:401-19.

[27] Diamond, Douglas and Ragu Rajan, 2009, "Illiquidity and Interest Rate Policy," University of Chicago, Mimeo.

[28] Eisfeldt, Andrea, 2004. "Endogenous Liquidity in Asset Markets," J. of Finance, 59:1-30.

[29] Faia, Ester and Tommaso Monacelli, 2007, "Optimal Interest Rate Rules, Asset Prices and Credit Frictions," J. of Econ. Dyn. and Control, 31:3228-3254.

[30] Fahri, Emmanuel and Jean Tirole, 2009, "Collective Moral Hazard, Systematic Risk and Bailouts," Harvard University and University of Toulouse, Mimeo.

[31] Fostel Ana and Geanakoplos, John and 2009, "Leverage Cycles and the Anxious Economy," Am. Econ. Rev. 98:1211-1244.

[32] Gertler, Mark, Simon Gilchrist and Fabio Natalucci, 2007, "External Constraint on Monetary Policy and the Financial Accelerator,' J. of Money, Credit and Bank. 39:295-330.

[33] Gertler, Mark and Peter Karadi, 2009, "A Model of Unconventional.Monetary Policy," New York University, Mimeo.

[34] Gilchrist, Simon, Vladimir Yankov and Egon Zakrasjek, 2009, "Credit Market Shocks and Economic Fluctuations: Evidence from Corporate Bond and Stock Markets," Boston University, Mimeo.

[35] Gilchrist, Simon, and John Leahy.2002 "Monetary Policy and Asset Prices", J. of Mon. Econ. 49:75-97.

[36] Goodfriend Marvin and Bennett McCallum, 2007, "Banking and Interest Rates in Monetary Policy Analysis," J. of Mon. Econ. 54:1480-1507.

[37] Gorton, Gary, 2010, Slapped in the Face by the Invisible Hand: The Panic of 200\%, Oxford: Oxford University Press. 
[38] Gourio, Francois. 2009, "Disaster Risk and Business Cycles," Boston University, Mimeo.

[39] He, Zhiguo and Arvind Krishnamurthy, 2008. "Intermediary Asset Pricing," Northwestern University, Mimeo.

[40] Holmstrom, Bengt and Jean Tirole,1997. "Financial Intermediation, Loanable Funds and the Real Sector," Quarterly J. of Econ. 112:663-691.

[41] Holmstrom, Bengt and Jean Tirole,1998. "Private and Public Supply of Liquidity," J. of Polit. Econ. 106:1-40.

[42] Iacoviello, Matteo, 2005, "House Prices, Borrowing Constraints and Monetary Policy in the Business Cycle," Am. Econ. Rev. 95:739-764.

[43] Jermann, Urban and Vincenzo Quadrini, 2009, "The Macroeconomic Effects of Financial Shocks," University of Pennsylvania and USC, Mimeo.

[44] Justiniano, Alejandro, Giorgio Primiceri and Andrea Tambalotti 2009, "Investment Shocks and Business Cycles," Northwestern University, Mimeo.

[45] Kehoe, Timothy, and David Levine, 1993. "Debt-constrained asset markets," Rev. Econ.Stud. 60:865-888.

[46] Kiyotaki, Nobuhiro and John Moore, 1997, "Credit Cycles," J. of Polit. Econ. 105:211-248.

[47] Kiyotaki, Nobuhiro and John Moore, 1997, "Credit Chains," LSE, Mimeo.

[48] Kiyotaki, Nobuhiro and John Moore, 2002, "Balance Sheet Contagion," Am. Econ. Rev. 85:46-50.

[49] Kiyotaki, Nobuhiro and John Moore, 2008, "Liquidity, Business Cycles and Monetary Policy," Princeton University and LSE, Mimeo.

[50] Korinek, Anton, 2009, "Systematic Risk-Taking Amplification Effects, Externalities and Regulatory Responses," University of Maryland, Mimeo. 
[51] Krishnamurthy, Arvind, 2003, "Collateral Constraints and the Amplification Mechanism," J. of Econ. Theory, 111:277-292.

[52] Kurlat, Pablo, 2009, "Lemons, Market Shutdowns and Learning, MIT, Mimeo.

[53] La'O, Jennifer, 2010. "Collateral Constraints and Noisy Fluctuations," MIT, Mimeo.

[54] Lorenzoni, Guido, 2008, "Inefficient Credit Booms," Rev. Econ. Stud. 75:809-833.

[55] Mendoza, Enrique, 2009, "Sudden Stops, Financial Crises and Leverage: A Fisherian Deflation of Tobin's Q," University of Maryland, Mimeo.

[56] Merton, Robert, 1973, "An Intertemporal Capital Asset Pricing Model," Econometrica, 41:867-887.

[57] Monacelli, Tommaso, 2009, "New Keynesian Models, Durable Goods and Collateral Constraints, J. of Mon. Econ. 56:242-254.

[58] Reinhart, Carmen M., and Kenneth Rogoff, 2009, This Time is Different: Eight Centuries of Financial Folly, Princeton University Press, Princeton, NJ.

[59] Reis, Ricardo, 2009. "Where Should Liquidity Be Injected During a Financial Crisis?" Columbia University, Miemo.

[60] Sargent, Thomas J., and Neil Wallace, 1983, "The Real Bills Doctrine versus the Quantity Theory of Money," J. of Polit. Econ. 90:1212-1236.

[61] Shleifer, Andrei and Rob Vishny, 2009, "Unstable Banking," Harvard University, Mimeo.

[62] Shleifer, Andrei and Rob Vishny, 2010, "Asset Fire Sales and Credit Easing," Harvard University, Mimeo.

[63] Smets, Frank and Raf Wouters, 2007, "Shocks and Frictions in U.S. Business Cycles: A Bayesian DSGE Approach," Am. Econ. Rev. 97:586606. 
[64] Townsend, Robert, 1979. "Costly State Verification" J. Econ. Theory, 21:265-293.

[65] Wallace, Neil, 1981. "A Modigliani-Miller Theorem for Open Market Operations", Am. Econ. Rev. 71:267-274.

[66] Williamson, Stephen,1987. "Financial Intermediation, Business Failures and Real Business Cycles," J. Polit Econ. 95:1196-1216. 
Table 1: Parameter Values for Baseline Model

\begin{tabular}{c|c|l}
\hline \multicolumn{3}{c}{ Households } \\
\hline$\beta$ & 0.990 & Discount rate \\
$\gamma$ & 0.500 & Habit parameter \\
$\chi$ & 5.584 & Relative utility weight of labor \\
$\varepsilon$ & 0.100 & Inverse Frisch elasticity of labor supply \\
\hline \multicolumn{3}{c}{ Financial Intermediaries } \\
\hline$\pi^{i}$ & 0.250 & Probability of new investment opportunities \\
\hline$\theta$ & 0.383 & Fraction of assets divertable: Perfect interbank market \\
& 0.129 & Fraction of assets divertable: Imperfect interbank market \\
$\xi$ & 0.003 & Transfer to entering bankers: Perfect interbank market \\
& 0.002 & Transfer to entering bankers: Imperfect interbank market \\
$\sigma$ & 0.972 & Survival rate of the bankers \\
\hline \multicolumn{3}{c}{ Intermediate good firms } \\
\hline$\alpha$ & 0.330 & Effective capital share \\
$\delta$ & 0.025 & Steady state depreciation rate \\
\hline \multicolumn{3}{c}{ Capital Producing Firms } \\
\hline$I f^{\prime \prime} / f^{\prime}$ & 1.500 & Inverse elasticity of net investment to the price of capital \\
\hline \multicolumn{3}{|c}{ Government } \\
$\frac{G}{Y}$ & 0.200 & Steady state proportion of government expenditures \\
\hline \hline
\end{tabular}




\section{Appendix 1: A General Model with Inter- bank Friction}

Here we lay out the general framework with an imperfect interbank market $(\omega<1)$. We abstract from outside equity and government interventions for the exposition. (Appendix 2 will present a framework that includes outside equity and government). For an equilibrium in which the bank makes loans, issues deposits and conducts interbank borrowing and lending, the first order

conditions for the bank's choice of $\left(s_{t}^{h}, d_{t}\right)$ are (14) and (15). The incentive constraint (16) can be rewritten as

$$
\begin{aligned}
& \left\{\left[\theta(1-\omega)+\nu_{b t}\right] Q_{t}^{h}-\nu_{s t}\right\} s_{t}^{h} \\
\leq & \left(\nu_{b t}-\theta \omega\right) n_{t}^{h}-\left(\theta \omega+\nu_{t}-\nu_{b t}\right) d_{t},
\end{aligned}
$$

where (70) holds with equality if $\lambda_{t}^{h}>0$, and the strict inequality implies $\lambda_{t}^{h}=0$. For the general case with $\omega<1$, we have from (15):

$$
\lambda_{t}^{h}=\frac{\frac{\nu_{s t}}{Q_{t}^{h}}-\nu_{b t}}{\theta(1-\omega)-\left(\frac{\nu_{s t}}{Q_{t}^{h}}-\nu_{b t}\right)} .
$$

The numerator indicates how much the value of the bank in type $\mathrm{h}$ island increases with an additional dollars' worth purchase of a security financed by interbank borrowing $\left(d s_{t}^{h}=1 / Q_{t}^{h}, d b_{t}^{h}=1\right)$. The denominator indicates how much the incentive constraint is tightened (i.e., RHS minus LHS of (11) increases) with an additional dollar purchase of the security.

As in the text, we conjecture that the price of security is lower in the investing region than the non-investing region due to abundant supply: $Q_{t}^{i}<$ $Q_{t}^{n}$. Then from (71), we learn

$$
\lambda_{t}^{i}>\lambda_{t}^{n} \geq 0
$$

From (14), we get

$$
\nu_{b t}-\nu_{t}=\frac{\theta \omega \bar{\lambda}_{t}}{1+\bar{\lambda}_{t}}>0 .
$$

Thus we learn that the marginal cost of interbank borrowing exceeds the marginal cost of deposit, $\nu_{b t}>\nu_{t}$. Using these first order conditions, (70) can be rewritten as

$$
Q_{t}^{h} s_{t}^{h} \leq \frac{1}{\theta(1-\omega)-\left(\frac{\nu_{s t}}{Q_{t}^{h}}-\nu_{b t}\right)}\left[\left(\nu_{b t}-\theta \omega\right) n_{t}^{h}-\frac{\theta \omega}{1+\bar{\lambda}_{t}} d_{t}\right]
$$


Substituting the first order conditions and the incentive constraint (74) into the value function (13), we learn

$$
V_{t}\left(s_{t}^{h}, b_{t}^{h}, d_{t}\right)=\left[\nu_{b t}+\lambda_{t}^{h}\left(\nu_{b t}-\theta \omega\right)\right] n_{t}^{h}+\theta \omega \frac{\bar{\lambda}_{t}-\lambda_{t}^{h}}{1+\bar{\lambda}_{t}} d_{t}
$$

The term $\nu_{b t}+\lambda_{t}^{h}\left(\nu_{b t}-\theta \omega\right)$ is the marginal value of net worth to the active banker: With an additional unit of net worth, the banker can reduce the interbank borrowing by one unit (which saves costs by $\nu_{b t}$ ), and relax the incentive constraint by $\nu_{b t}-\theta \omega$ (which increases the value of bank by $\lambda_{t}^{h}$ times as much). Substituting this expression for date $t+1$ into the Bellman equation (??) yields

$$
\begin{aligned}
V_{t}\left(s_{t}^{h}, b_{t}^{h}, d_{t}\right) & =\nu_{s t} s_{p t}-\nu_{b t} b_{t}-\nu_{t} d_{t} \\
& =\underset{h^{\prime}}{E_{t} \Lambda_{t, t+1} \Omega_{t+1}^{h^{\prime}} n_{t+1}^{h^{\prime}}}
\end{aligned}
$$

where

$$
\Omega_{t}^{h}=1-\sigma+\sigma\left[\nu_{b t}+\lambda_{t}^{h}\left(\nu_{b t}-\theta \omega\right)\right]
$$

is the marginal value of net worth for the banker, who exits with probability $1-\sigma$ and stays active with probability $\sigma$. Applying the method of undetermined coefficient to (75), we learn

$$
\begin{aligned}
\nu_{b t} & =R_{b t+1} \underset{h^{\prime}}{E_{t} \Lambda_{t, t+1} \Omega_{t+1}^{h^{\prime}}}, \\
\nu_{t} & =R_{t+1} \underset{h^{\prime}}{E_{t} \Lambda_{t, t+1}} \Omega_{t+1}^{h^{\prime}}=\frac{R_{t+1}}{R_{b t+1}} \nu_{b t}, \\
\nu_{s t} & =\underset{h^{\prime}}{E_{t} \Lambda_{t, t+1} \Omega_{t+1}^{h^{\prime}}\left[Z_{t+1}+(1-\delta) Q_{t+1}^{h^{\prime}}\right] \psi_{t+1} .}
\end{aligned}
$$

Let $D_{t}$ be aggregate value of deposit of the banks. Then from $(72,74)$, we have

$$
\begin{gathered}
Q_{t}^{i} S_{t}^{i}=\frac{1}{\theta(1-\omega)-\left(\frac{\nu_{s t}}{Q_{t}^{i}}-\nu_{b t}\right)}\left[\left(\nu_{b t}-\theta \omega\right) N_{t}^{i}-\frac{\theta \omega}{1+\bar{\lambda}_{t}} \pi^{i} D_{t}\right], \\
Q_{t}^{n} S_{t}^{n} \leq \frac{1}{\theta(1-\omega)-\left(\frac{\nu_{s t}}{Q_{t}^{n}}-\nu_{b t}\right)}\left[\left(\nu_{b t}-\theta \omega\right) N_{t}^{n}-\frac{\theta \omega}{1+\bar{\lambda}_{t}} \pi^{n} D_{t}\right],
\end{gathered}
$$


where (81) holds with equality if $\lambda_{t}^{n}>0$, and the strict inequality implies $\lambda_{t}^{n}=0$. The marginal propensity to buy assets with respect to net worth is

$$
\phi_{t}^{h}=\frac{\nu_{b t}-\theta \omega}{\theta(1-\omega)-\left(\frac{\nu_{s t}}{Q_{t}^{h}}-\nu_{b t}\right)}
$$

which is the expression for the leverage ratio in the general case of an imperfect interbank market. (Observe this expression becomes (27) and (28) if $\omega=0)$.

The rest of the framework is the same as the model in the text. From $(34,35,36)$, the aggregate net worth of the bank in investing islands and non-investing islands satisfies

$$
N_{t}^{h}=\pi^{h}\left\{\left[Z_{t}+(1-\delta) Q_{t}^{h}\right] \psi_{t}(\sigma+\xi) S_{t-1}-\sigma R_{t} D_{t-1}\right\} .
$$

$\left(A_{t}, \psi_{t}\right)$ follows an exogenous stochastic process. Then, four prices $\left(Q_{t}^{i}, Q_{t}^{n}, R_{t+1}, R_{b t+1}\right)$ and eleven quantities $\left(Y_{t}, C_{t}, L_{t}, I_{t}, K_{t+1}, Z_{t}, D_{t}, N_{t}^{i}, N_{t}^{n}, S_{t}^{i}, S_{t}^{n}\right)$ together with five shadow prices $\left(\nu_{t}, \nu_{b t}, \nu_{s t}, \lambda_{t}^{i}, \lambda_{t}^{n}\right)$ are determined as a function of the state variables $\left(K_{t}, C_{t-1}, I_{t-1}, A_{t}, \psi_{t}, R_{t}, D_{t-1}\right)$ by the sequence of twenty equations: the optimization conditions of households and non-financial firms $(1,2,7,39,40)$, the optimization of banks $(71 i, 71 n, 73,77-81,82 i, 82 n$,$) ,$ and the market clearing conditions for goods, interbank market funds, securities and labor $(3,37,41 i, 41 n, 42)$.

\subsection{Steady State}

In the steady state, we have

$$
\begin{aligned}
I & =\delta K \\
C & =\left[A\left(\frac{L}{K}\right)^{1-\alpha}-\delta\right] K \\
\chi L^{\varphi} & =(1-\alpha) A\left(\frac{K}{L}\right)^{\alpha} \frac{1-\beta \gamma}{1-\gamma} \frac{1}{C} \\
Z & =\alpha A\left(\frac{L}{K}\right)^{1-\alpha}
\end{aligned}
$$




$$
\begin{aligned}
R & =\frac{1}{\beta} \\
Q^{i} & =1
\end{aligned}
$$

We also have

$$
\begin{aligned}
N^{i} & =\pi^{i}\left[(\sigma+\xi)(Z+1-\delta) K-\frac{\sigma}{\beta} D\right], \\
N^{n} & =\pi^{n}\left[(\sigma+\xi)\left[Z+(1-\delta) Q^{n}\right] K-\frac{\sigma}{\beta} D\right], \\
N^{i}+N^{n}+D & =K+\pi^{n}\left(Q^{n}-1\right)(1-\delta) K .
\end{aligned}
$$

The security market equilibrium implies

$$
\begin{aligned}
{\left[\delta+\pi^{i}(1-\delta)\right] K } & =\frac{1}{\theta(1-\omega)+\nu_{b}-\nu_{s t}}\left[\left(\nu_{b}-\theta \omega\right) N^{i}+\frac{\pi^{i} \theta \omega}{1+\bar{\lambda}} D\right] \\
Q^{n} \pi^{n}(1-\delta) K & \leq \frac{1}{\theta(1-\omega)+\nu_{b}-\frac{\nu_{s t}}{Q^{n}}}\left[\left(\nu_{b}-\theta \omega\right) N^{n}+\frac{\pi^{n} \theta \omega}{1+\bar{\lambda}} D\right]
\end{aligned}
$$

where equality holds if $\lambda^{n}>0$ while the strict inequality implies $\lambda^{n}=0$. Concerning the optimization of the bank, we have

$$
\begin{gathered}
\lambda^{i}=\frac{\nu_{s}-\nu_{b}}{\theta(1-\omega)-\left(\nu_{s}-\nu_{b}\right)}, \\
\lambda^{n}=\frac{\frac{\nu_{s}}{Q^{n}}-\nu_{b}}{\theta(1-\omega)-\left(\frac{\nu_{s}}{Q^{n}}-\nu_{b}\right)}, \\
\nu_{b}=\beta R_{b}\left[1-\sigma+\sigma \nu_{b}+\sigma \bar{\lambda}\left(\nu_{b}-\theta \omega\right)\right] \\
\nu_{b}-\nu=\left(1-\frac{1}{\beta R_{b}}\right) \nu_{b}=\frac{\theta \omega \bar{\lambda}}{1+\bar{\lambda}}, \\
\nu_{s}=\beta \pi^{i}(Z+1-\delta)\left[1-\sigma+\sigma \nu_{b}+\sigma \lambda^{i}\left(\nu_{b}-\theta \omega\right)\right] \\
+\beta \pi^{n}\left[Z+Q^{n}(1-\delta)\right]\left[1-\sigma+\sigma \nu_{b}+\sigma \lambda^{n}\left(\nu_{b}-\theta \omega\right)\right]
\end{gathered}
$$

The steady state equilibrium is recursive: The values of eleven prices and ratio variables $\left(R_{b}, Q^{n}, Z, \lambda^{i}, \lambda^{n}, \nu_{b}, \nu, \nu_{s}, \frac{N^{i}}{K}, \frac{N^{n}}{K}, \frac{D}{K}\right)$ are determined by eleven equations $(89-98)$ where $(97)$ has two equations. Then quantity variables $(K, I, C, L)$ are determined by $(83-86)$. 


\section{Appendix 2: A General Model with Out- side Equity and Government Intervention}

Here we lay out a general framework with an imperfect interbank market $(\omega<$ 1) and with outside equity and credit policies. At the beginning of each period (before the arrival of investment opportunity to nonfinancial firms), each bank learns whether to exit or stay active at the end of this period. The active bank raises fund from households by issuing deposit $d_{t}$ and outside equity $e_{t}$ at price $q_{t}$. The government may buy additional equity $s_{\text {get }}-(1-\delta) \psi_{t} s_{\text {get }}$ from active banks at price $Q_{g t}$. Outside equity held by households and government both pays the same dividend as a security issued by non-financial firms. During the period (after the arrival of investment opportunity to nonfinancial firms), the active bank can raise funds by borrowing at interbank market $b_{t}^{h}$ and at the discount window $m_{t}^{h}$ in order to partially finance the loan (purchase of security of the nonfinancial firms). The flow of fund constraint of an active bank on type $h$ island is

$$
Q_{t}^{h} s_{p t}^{h}=n_{t}^{h}+b_{t}^{h}+m_{t}^{h}+q_{t} e_{t}+d_{t}
$$

where $s_{p t}^{h}=s_{t}^{h}-s_{g e t}$ is the private holding of the security. The net worth of active bank is defined similarly to (57) as

$$
\begin{aligned}
n_{t}^{h}= & {\left[Z_{t}+(1-\delta) Q_{t}^{h}\right] \psi_{t} s_{p t-1}-\left[Z_{t}+(1-\delta) q_{t}\right] \psi_{t} e_{t-1}-R_{b t} b_{t-1} } \\
& -R_{m t} m_{t-1}-R_{t} d_{t-1}+\left(Q_{g t}-Q_{t}^{h}\right)\left[s_{g e t}-(1-\delta) \psi_{t} s_{g e t-1}\right]
\end{aligned}
$$

The last term is the government "gift" to each banker via an equity injection. Because we assume the government gives the gift to bankers lump sum (including the new entrants), we have $s_{\text {get }}=S_{\text {get }} / f$. The value of the bank at the end of this period is equal to the expected present value of the future dividend (which is equal to the net worth at the time of exit):

$$
V_{t}=E_{t} \sum_{i=1}^{\infty}(1-\sigma) \sigma^{i-1} \Lambda_{t, t+i} \widetilde{n}_{t+i}^{h}
$$

where the net worth of the exiting bank does not include the gift:

$$
\begin{aligned}
\widetilde{n}_{t}^{h}= & {\left[Z_{t}+(1-\delta) Q_{t}^{h}\right] \psi_{t} s_{p t-1}-\left[Z_{t}+(1-\delta) q_{t}\right] \psi_{t} e_{t-1}-R_{b t} b_{t-1} } \\
& -R_{m t} m_{t-1}-R_{t} d_{t-1} .
\end{aligned}
$$


The incentive constraint implies the value of the active bank must be at least as large as the value of divertable assets:

$$
V_{t}\left(s_{p t}^{h}, b_{t}^{h}, m_{t}^{h}, e_{t}, d_{t}\right) \geq \theta\left(Q_{t}^{h} s_{p t}^{h}-\omega b_{t}^{h}-\omega_{g} m_{t}^{h}-\omega_{e} q_{t} e_{t}\right) .
$$

As in the text, we assume the bank cannot divert assets acquired by government equity injection. On the other hand, the bank can divert the asset financed by outside equity more easily than the deposit, i.e., $\omega_{e}<0$.

Guessing the value function is linear in the arguments yields:

$$
\begin{aligned}
V_{t}^{h} & =V_{t}\left(s_{t}^{h}, b_{t}^{h}, m_{t}^{h}, e_{t}, d_{t}\right) \\
& =\nu_{s t} s_{p t}-\nu_{b t} b_{t}-\nu_{m t} m_{t}-\nu_{e t} e_{t}-\nu_{t} d_{t}+\nu_{g e t},
\end{aligned}
$$

and let $\lambda_{t}^{h}$ be the Lagrangian multiplier for the incentive constraint of the bank in $h$ island. Then using (99), the Lagrangian is

$$
\begin{aligned}
\mathcal{L}= & V_{t}^{h}+\lambda_{t}^{h}\left[V_{t}^{h}-\theta\left(Q_{t}^{h} s_{p t}^{h}-\omega b_{t}^{h}-\omega_{g} m_{t}^{h}-\omega_{e} q_{t} e_{t}\right)\right] \\
= & \left(1+\lambda_{t}^{h}\right)\left[\left(\nu_{s t}-\nu_{b t} Q_{t}^{h}\right) s_{p t}^{h}+\left(\nu_{b t}-\nu_{m t}\right) m_{t}^{h}+\left(\nu_{b t}-\nu_{t}\right) d_{t}\right. \\
& \left.+\left(\nu_{b t} q_{t}-\nu_{e t}\right) e_{t}+\nu_{b t} n_{t}+\nu_{g e t}\right] \\
& -\lambda_{t}^{h} \theta\left[(1-\omega) Q_{t}^{h} s_{p t}^{h}+\left(\omega-\omega_{g}\right) m_{t}^{h}+\left(\omega-\omega_{e}\right) q_{t} e_{t}+\omega\left(n_{t}^{h}+d_{t}\right)\right] .
\end{aligned}
$$

We focus on the equilibrium in which the bank makes loans, deposits and conducts interbank borrowing and lending, but may or may not issue outside equity or use the discount window. Then, the first order conditions for the bank's choice of $\left(s_{t}^{h}, m_{t}^{h}, e_{t}, d_{t}\right)$ are given by $(14,15)$ in the text and

$$
\begin{aligned}
\left(1+\lambda_{t}^{h}\right)\left(\nu_{b t}-\nu_{m t}\right) & \leq \theta\left(\omega-\omega_{g}\right) \lambda_{t}^{h}, \quad\left(=\text { if } m_{t}^{h}>0\right) \\
\left(1+\bar{\lambda}_{t}\right)\left(\nu_{b t} q_{t}-\nu_{e t}\right) & \leq \theta\left(\omega-\omega_{e}\right) \bar{\lambda}_{t} q_{t},\left(=\text { if } e_{t}>0\right) .
\end{aligned}
$$

The incentive constraint (101) can be rewritten as

$$
\begin{aligned}
& \left\{\left[\theta(1-\omega)+\nu_{b t}\right] Q_{t}^{h}-\nu_{s t}\right\} s_{t}^{h} \\
\leq & \left(\nu_{b t}-\theta \omega\right) n_{t}^{h}-\left(\theta \omega+\nu_{t}-\nu_{b t}\right) d_{t}-\left[\theta\left(\omega-\omega_{g}\right)+\nu_{m t}-\nu_{b t}\right] m_{t}^{h} \\
& -\left[\theta\left(\omega-\omega_{e}\right) q_{t}+\nu_{e t}-\nu_{b t} q_{t}\right] e_{t}+\nu_{g e t},
\end{aligned}
$$

where (105) holds with equality if $\lambda_{t}^{h}>0$, and the strict inequality implies $\lambda_{t}^{h}=0$. 
From (103), we learn

$$
\nu_{m t}-\nu_{b t} \geq \frac{\theta\left(\omega_{g}-\omega\right) \lambda_{t}^{i}}{1+\lambda_{t}^{i}}>\frac{\theta\left(\omega_{g}-\omega\right) \lambda_{t}^{n}}{1+\lambda_{t}^{n}} .
$$

Thus banks in non-investing island do not use the discount window borrowing, while banks in investing island use it only if the first weak inequality holds with equality. We also learn from (106) that the marginal cost of discount window has to be larger than the marginal cost of interbank borrowing $\left(\nu_{m t}>\nu_{b t}\right)$ when both facilities are used. From (104), we have

$$
\nu_{b t} q_{t}-\nu_{e t} \leq \frac{\theta\left(\omega-\omega_{e}\right) \bar{\lambda}_{t}}{1+\bar{\lambda}_{t}} q_{t}, \quad\left(=\text { if } e_{t}>0\right) .
$$

Thus, in order for the bank to issue outside equity to the households, the marginal benefit of saving the cost of interbank borrowing must be larger than the marginal cost of outside equity $\left(\nu_{b t} q_{t}>\nu_{e t}\right)$, when the bank can divert the asset more easily when financed by outside equity than interbank borrowing $\left(\omega>\omega_{e}\right)$. Using these first order conditions, (105) can be rewritten as

$$
\begin{aligned}
& {\left[\theta(1-\omega)-\left(\frac{\nu_{s t}}{Q_{t}^{h}}-\nu_{b t}\right)\right] Q_{t}^{h} s_{t}^{h} } \\
\leq & \left(\nu_{b t}-\theta \omega\right) n_{t}^{h}+\frac{\theta\left(\omega_{g}-\omega\right)}{1+\lambda_{t}^{h}} m_{t}^{h}-\frac{\theta}{1+\bar{\lambda}_{t}}\left[\omega d_{t}+\left(\omega-\omega_{e}\right) q_{t} e_{e}\right]+\nu_{g e t}(108)
\end{aligned}
$$

Substituting the first order conditions and the incentive constraint (108) into the value function (102), we learn

$$
\begin{aligned}
V_{t}^{h}= & {\left[\nu_{b t}+\lambda_{t}^{h}\left(\nu_{b t}-\theta \omega\right)\right] n_{t}^{h} } \\
& +\theta \frac{\bar{\lambda}_{t}-\lambda_{t}^{h}}{1+\bar{\lambda}_{t}}\left[\omega d_{t}+\left(\omega-\omega_{e}\right) q_{t} e_{e}\right]+\left(1+\lambda_{t}^{h}\right) \nu_{\text {get }} .
\end{aligned}
$$

Substituting this expression for date $t+1$ into the Bellman equation (102), we learn

$$
\begin{aligned}
V_{t} & =\nu_{s t} s_{p t}-\nu_{b t} b_{t}-\nu_{m t} m_{t}-\nu_{e t} e_{t}-\nu_{t} d_{t}+\nu_{g e t} \\
& =\underset{h_{t}^{\prime}}{E_{t, t+1}}\left[\Omega_{t+1}^{h^{\prime}} n_{t+1}^{h^{\prime}}+\sigma\left(1+\lambda_{t+1}^{h^{\prime}}\right) \nu_{\text {get+1 }}\right],
\end{aligned}
$$


where $\Omega_{t}^{h}$ is given by (76). Applying the method of undetermined coefficient to $(109)$, we learn $(77-79)$ and

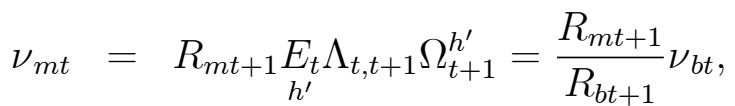

$$
\begin{aligned}
& \nu_{e t}=\underset{h^{\prime}}{E_{t}} \Lambda_{t, t+1} \Omega_{t+1}^{h^{\prime}}\left[Z_{t+1}+(1-\delta) q_{t+1}\right] \psi_{t+1} \\
& \nu_{\text {get }}=\underset{h^{\prime}}{E_{t}} \Lambda_{t, t+1} \sigma\left\{\left(1+\lambda_{t+1}^{h^{\prime}}\right) \nu_{g e t+1}+\sigma\left[\nu_{b t+1}+\lambda_{t+1}^{h^{\prime}}\left(\nu_{b t+1}-\theta \omega\right)\right]\right. \\
& \left.\cdot\left(Q_{g t+1}-Q_{t+1}^{h}\right)\left[s_{g e t+1}-(1-\delta) \psi_{t} s_{g e t}\right]\right\} \text {. }
\end{aligned}
$$

Let $M_{t}, \bar{E}_{t}$ and $D_{t}$ be aggregate value of discount window borrowing, outside equity and deposit of the banks. Then from (108), we have

$$
\begin{gathered}
S_{p t}^{i}=\frac{1}{\left[\theta(1-\omega)+\nu_{b t}\right] Q_{t}^{i}-\nu_{s t}} \cdot\left\{\left(\nu_{b t}-\theta \omega\right) N_{t}^{i}+\frac{\theta\left(\omega_{g}-\omega\right)}{1+\lambda_{t}^{h}} M_{t}\right. \\
\left.-\frac{\pi^{i} \theta}{1+\bar{\lambda}_{t}}\left[\omega D_{t}+\left(\omega-\omega_{e}\right) q_{t} \bar{E}_{t}\right]+\pi^{i} f \nu_{g e t}\right\} \\
S_{p t}^{n} \leq \frac{1}{\left[\theta(1-\omega)+\nu_{b t}\right] Q_{t}^{n}-\nu_{s t}} \cdot\left\{\left(\nu_{b t}-\theta \omega\right) N_{t}^{n}\right. \\
\left.\quad-\frac{\pi^{n} \theta}{1+\bar{\lambda}_{t}}\left[\omega D_{t}+\left(\omega-\omega_{e}\right) q_{t} \bar{E}_{t}\right]+\pi^{n} f \nu_{g e t}\right\},
\end{gathered}
$$

where (115) holds with equality if $\lambda_{t}^{n}>0$, and the strict inequality implies $\lambda_{t}^{n}=0$. The aggregate net worth of the banks in investing islands and non-investing islands are similar to (59) as

$$
\begin{aligned}
N_{t}^{h}= & \pi^{h}\left\{\left[Z_{t}+(1-\delta) Q_{t}^{h}\right] \psi_{t}(\sigma+\xi) S_{p t-1}-\sigma\left[Z_{t}+(1-\delta) q_{t}\right] \psi_{t} \bar{E}_{t-1}\right. \\
& \left.-\sigma R_{m t} M_{t-1}-\sigma R_{t} D_{t-1}+\sigma\left(Q_{g t^{-}} Q_{t}^{h}\right)\left[S_{g e t^{-}}(1-\delta) \psi_{t} S_{g e t-1}\right]\right\} .(11
\end{aligned}
$$

The security market equilibrium implies

$$
\begin{aligned}
I_{t}+\pi^{i}(1-\delta) K_{t} & =S_{p t}^{i}+S_{g t}^{i}+\pi^{i} S_{g e t} \\
\pi^{n}(1-\delta) K_{t} & =S_{p t}^{n}+S_{g t}^{n}+\pi^{n} S_{g e t} .
\end{aligned}
$$

The flow of fund constraint of entire banking sector (which implies the interbank market clearing) is

$$
Q_{t}^{i} S_{p t}^{i}+Q_{t}^{n} S_{p t}^{n}=N_{t}^{i}+N_{t}^{n}+M_{t}+D_{t}+q_{t} \bar{E}_{t} .
$$


The rest of the framework is the same as the model in the text, except that the household's budget constraint (5) includes the purchase of the outside equity

$$
\begin{aligned}
C_{t}= & W_{t} L_{t}+\Pi_{t}-T_{t}+R_{t}\left(D_{t}+D_{g t}\right)-\left(D_{t+1}+D_{g t+1}\right) \\
& +\left[Z_{t}+(1-\delta) q_{t}\right] \psi_{t} \bar{E}_{t-1}-q_{t} \bar{E}_{t} .
\end{aligned}
$$

Thus the first order condition for the outside equity purchase is

$$
q_{t}=E_{t}\left\{\Lambda_{t, t+1}\left[Z_{t+1}+(1-\delta) q_{t+1}\right] \psi_{t+1}\right\}
$$

Comparing this expression of household's valuation of equity and the banker's valuation (111), we learn that the household's discount factor is the marginal rate of substitution of consumption $\Lambda_{t, t+1}$, while the banker's discount factor is the marginal rate of substitution times the marginal value of net worth $\Lambda_{t, t+1} \Omega_{t+1}^{h^{\prime}}$. And the banker's discount factor is more volatile than the household's over the business cycle.

The government chooses the policy rule to determine $\left(G_{t}, T_{t}, S_{g t}^{h}, S_{g e t}, Q_{g t}, D_{g t}, R_{m t+1}\right)$. $\left(A_{t}, \psi_{t}\right)$ follows an exogenous stochastic process. Then, five prices $\left(Q_{t}^{i}, Q_{t}^{n}, q_{t}, R_{t+1}, R_{b t+1}\right)$ and thirteen quantities $\left(Y_{t}, C_{t}, L_{t}, I_{t}, K_{t+1}, Z_{t}, M_{t}, \bar{E}_{t}, D_{t}, N_{t}^{i}, N_{t}^{n}, S_{p t}^{i}, S_{p t}^{n}\right)$ together with eight shadow prices $\left(\nu_{t}, \nu_{b t}, \nu_{m t}, \nu_{s t}, \nu_{e t}, \nu_{g e t}, \lambda_{t}^{i}, \lambda_{t}^{n}\right)$ are determined as a function of the state variables $\left(K_{t}, C_{t-1}, I_{t-1}, A_{t}, \psi_{t}, R_{t} D_{t-1}, R_{t} D_{g t-1}\right.$, $\left.R_{m t} M_{t-1}, \bar{E}_{t-1}, S_{g t-1}, S_{g e t-1}\right)$.by the sequence of twenty six equations: the optimization conditions of households and non-financial firms $(1,2,7,39,40,120)$, the optimization of banks $(71 i, 71 n, 73,77-79,106,107,110-115,116 i, 116 n)$, and the market clearing conditions for goods, labor, securities and interbank market $(3,42,117,118,119)$. 
Figure 1. Crisis Experiment: Perfect Interbank Market
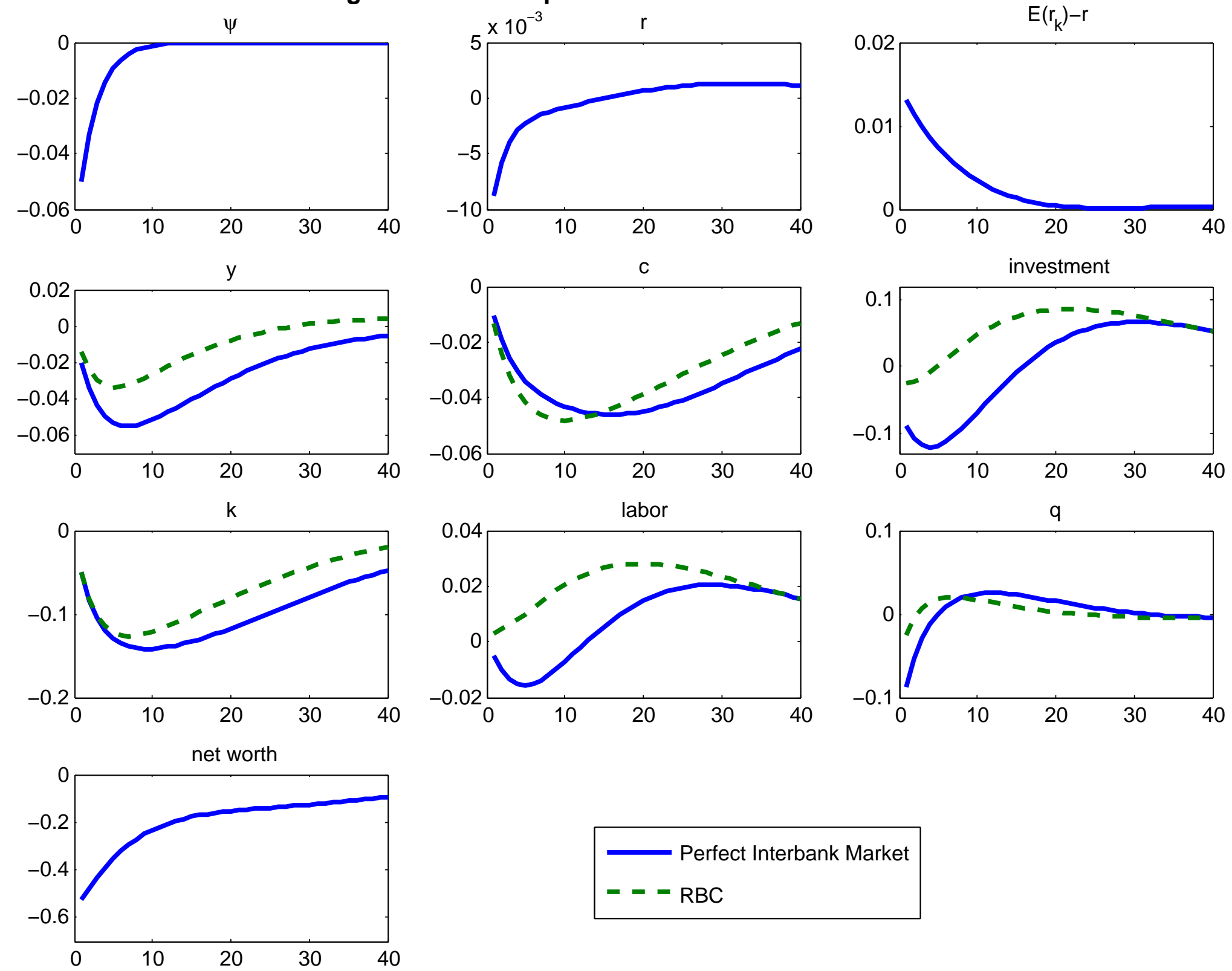
Figure 2. Crisis Experiment: Imperfect Interbank Market
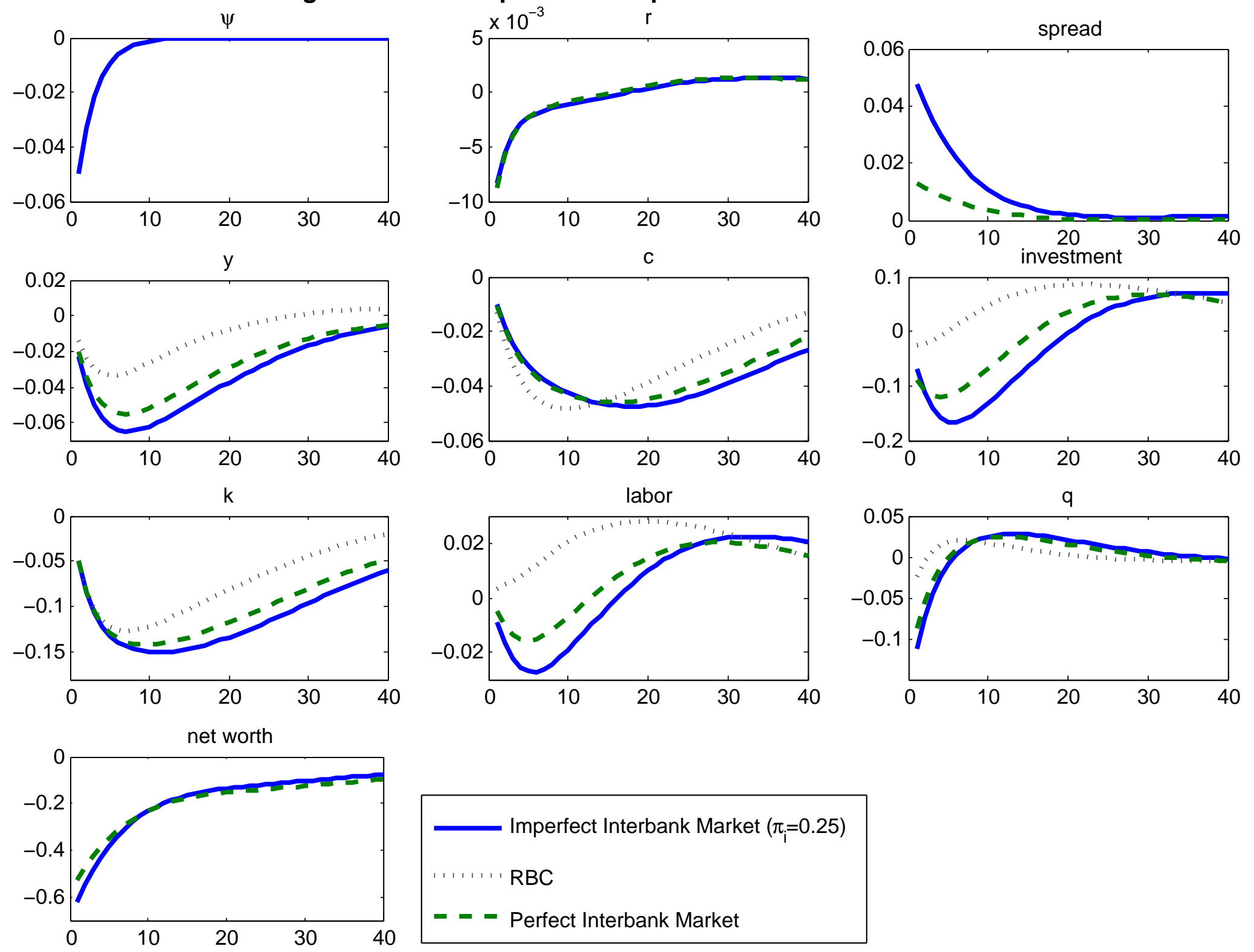
Figure 3. Lending Facilities: Perfect Interbank Market
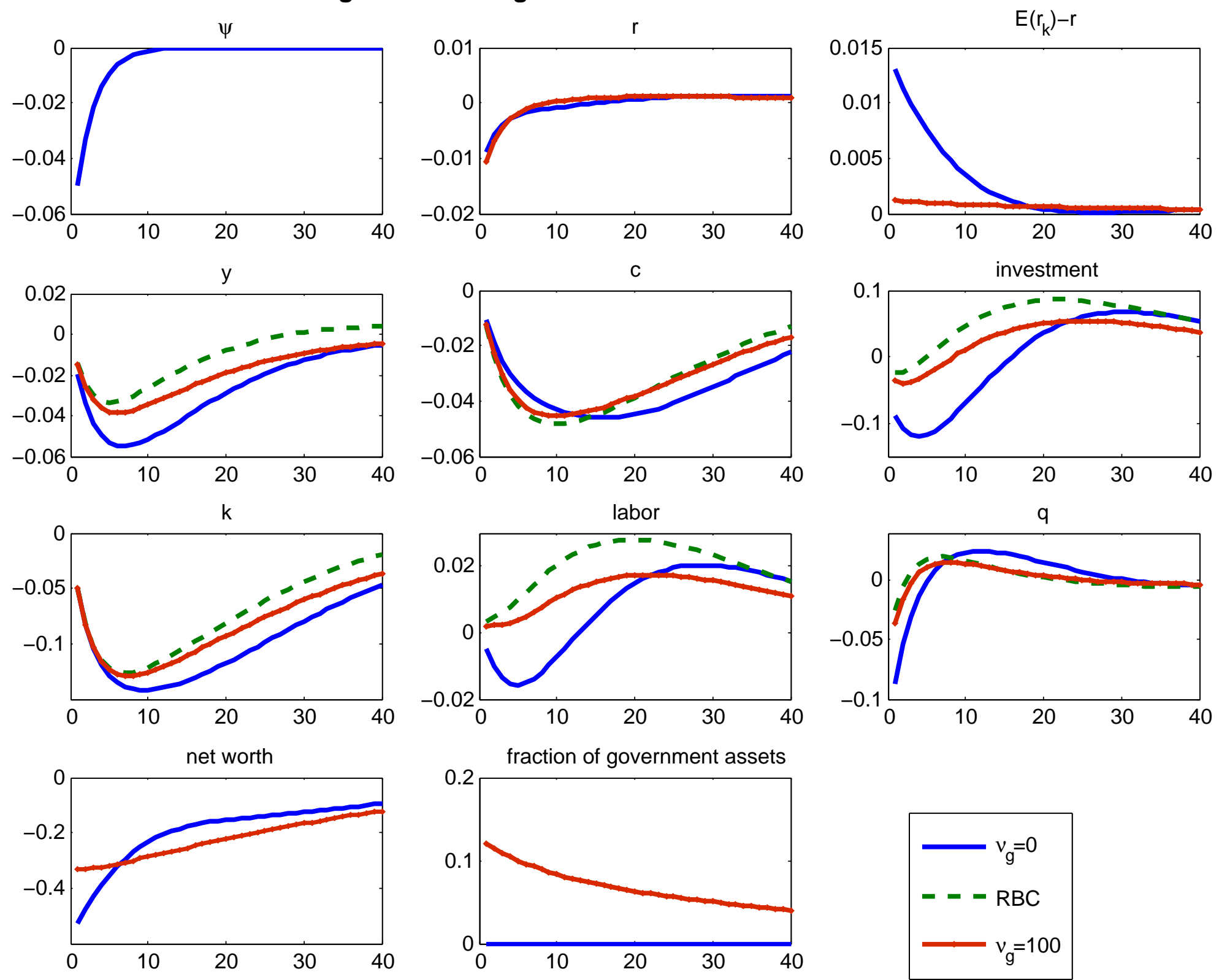
Figure 4. Lending Facilities: Imperfect Interbank Market
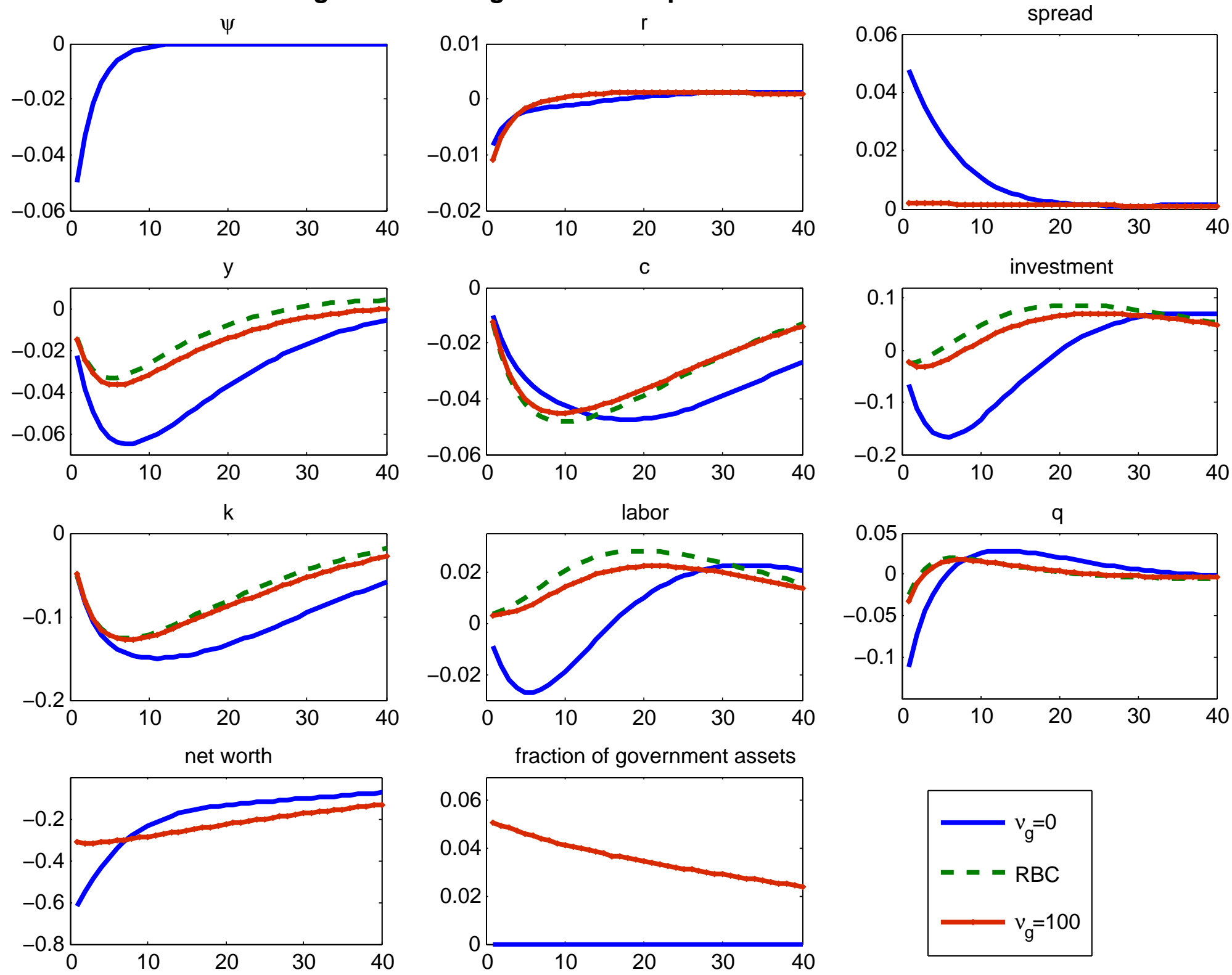